\title{
Oil from transgenic Camelina sativa containing over $25 \% n-3$ long-chain PUFA as the major lipid source in feed for Atlantic salmon (Salmo salar)
}

\author{
Mónica B. Betancor ${ }^{1 *}$, Keshuai Li $^{2}$, Valentin S. Bucerzan ${ }^{1}$, Matthew Sprague ${ }^{1}$, Olga Sayanova ${ }^{3}$, \\ Sarah Usher ${ }^{3}$, Lihua $\mathrm{Han}^{3}$, Fernando Norambuena ${ }^{4}$, Ole Torrissen ${ }^{5}$, Johnathan A. Napier ${ }^{3}$, \\ Douglas R. Tocher ${ }^{1}$ and Rolf E. Olsen ${ }^{2}$ \\ ${ }^{1}$ Institute of Aquaculture, Faculty of Natural Sciences, University of Stirling, Stirling FK9 4LA, UK \\ ${ }^{2}$ Department of Biology, Norwegian University of Science and Technology, 7491 Trondheim, Norway \\ ${ }^{3}$ Department of Biological Chemistry and Crop Protection, Rothamsted Research, Harpenden AL5 2JQ, UK \\ ${ }^{4}$ Biomar AS, Havnegata 9, Pirsenteret 3, Trondheim 7010, Norway \\ ${ }^{5}$ Institute of Marine Research, Matre 5984, Matredal, Norway
}

(Submitted 8 February 2018 - Final revision received 23 March 2018 - Accepted 1 April 2018)

\begin{abstract}
Facing a bottleneck in the growth of aquaculture, and a gap in the supply and demand of the highly beneficial $n$ - 3 long-chain PUFA (LC-PUFA), sustainable alternatives to traditional marine-based feeds are required. Therefore, in the present trial, a novel oil obtained from a genetically engineered oilseed crop, Camelina sativa, that supplied over $25 \% n$-3 LC-PUFA was tested as a sole dietary-added lipid source in Atlantic salmon (Salmo salar) feed. Three groups of fish were fed three experimental diets for 12 weeks with the same basal composition and containing $20 \%$ added oil supplied by either a blend of fish oil and rapeseed oil (1:3) (COM) reflecting current commercial formulations, wild-type Camelina oil (WCO) or the novel transgenic Camelina oil (TCO). There were no negative effects on the growth, survival rate or health of the fish. The whole fish and flesh $n$-3 LC-PUFA levels were highest in fish fed TCO, with levels more than 2-fold higher compared with those of fish fed the COM and WCO diets, respectively. Diet TCO had no negative impacts on the evaluated immune and physiological parameters of head kidney monocytes. The transcriptomic responses of liver and mid-intestine showed only mild effects on metabolism genes. Overall, the results clearly indicated that the oil from transgenic Camelina was highly efficient in supplying $n$ - 3 LC-PUFA providing levels double that obtained with a current commercial standard, and similar to those a decade ago before substantial dietary fishmeal and oil replacement.
\end{abstract}

Key words: EPA: DHA: Camelina: Aquaculture: Fish oil

Fish is recognised as a nutritious and healthy food partly owing to the fact that they are naturally rich in the health-promoting $n$-3 long-chain PUFA (LC-PUFA), EPA (20:5n-3) and DHA $(22: 6 n-3)^{(1,2)}$. Much of the fish consumed today is farmed ${ }^{(3)}$, many reared on feeds containing high levels of more sustainable raw materials such as plant meals and oils of agricultural origin. Such terrestrial ingredients are devoid of $n-3$ LC-PUFA and, therefore, the use of these plant ingredients translates into reduced levels of beneficial $n$-3 LC-PUFA in the fillet of the fish, as has been documented in farmed Atlantic salmon (Salmo salar) from 2006 onwards $^{(4)}$. This means that larger or more portions of farmed fish must be consumed in order to obtain the recommended EPA and DHA intake suggested by different agencies (e.g. International Society for the Study of Fatty Acids and Lipids ${ }^{(5)}$ and European Food Safety Authority $\left.{ }^{(6)}\right)$.
Oilseed crops are major agricultural products with a highly organised and well-established infrastructure for their cultivation, harvest and processing, as well as distribution, marketing and utilisation of vegetable oils $(\mathrm{VO})^{(7)}$. Thus, VO have been the main alternatives to dietary fish oil (FO) in aquafeeds and, although these oils are devoid of $n$-3 LC-PUFA, they can be rich in shorter-chain PUFA such as 18:3n-3. This opens up the possibility for genetic modification to enable the desaturation and elongation of 18:3n-3 to EPA and DHA. Recently, transgenic Camelina sativa crops, capable of producing either EPA or EPA and DHA in their seeds, have been developed ${ }^{(8,9)}$. Two such oils have been evaluated as replacements for dietary FO in feeds for Atlantic salmon ${ }^{(10-13)}$ and gilthead sea bream (Sparus aurata) $^{(14)}$ showing promising results, enabling good fish growth and deposition of $n$-3 LC-PUFA in tissues including

Abbreviations: ADC, apparent digestibility coefficient; cDNA, complementary DNA; COM, fish oil/rapeseed oil feed; DEG, differentially expressed genes; FC, fold-change; FO, fish oil; LC-PUFA, $n$-3 long-chain PUFA; LPS, lipopolysaccharide; PC, pyloric caeca; TCO, transgenic Camelina oil feed; VO, vegetable oil; WCO, wild-type Camelina oil feed.

* Corresponding author: M. B. Betancor, email m.b.betancor@stir.ac.uk 
flesh. In contrast, feeds formulated with high levels of conventional plant ingredients, including VO, can adversely affect fish health through impacts on immune and stress responses ${ }^{(15)}$. A well-balanced dietary fatty acid profile, particularly in terms of LC-PUFA, is a determinant of animal health and welfare and, thus, the replacement of FO by VO can alter this balance. In previous trials, no major impacts on fish health were observed after feeding fish with oil from transgenic Camelina supplying $12 \% \mathrm{EPA}+\mathrm{DHA}$ with, specifically, no detrimental effects on immune function ${ }^{(12)}$ or response after an environmental stress ${ }^{(13)}$. However, the outcome of stress responses in fish fed $\mathrm{VO}$ will depend on the intensity and type of the stressor, as well as its duration ${ }^{(16)}$, and therefore different stressors may have different effects on particular immune or inflammatory responses.

In previous studies, oils from transgenic Camelina supplying either $20 \%$ EPA or $6 \%$ each of EPA and DHA were tested in Atlantic salmon against 'gold-standard' feeds formulated with high fishmeal and $\mathrm{FO}^{(10-12)}$. The oil supplying $6 \%$ each of EPA and DHA was subsequently tested in Atlantic salmon against feeds formulated with lower fishmeal and $\mathrm{FO}^{(13)}$. In the present study, a third-generation oil supplying levels of EPA, DHA and total $n$-3 LC-PUFA greater than most FO was tested in feeds for Atlantic salmon with even lower levels of fishmeal and FO reflecting current commercial salmon feeds. Thus, triplicate groups of Atlantic salmon were fed one of three experimental diets formulated with $30 \%$ fishmeal and $43 \%$ plant meals that contained a mix of FO and rapeseed oil (1:3) (diet COM), wildtype Camelina oil (diet WCO) or transgenic Camelina oil (diet TCO) in order to evaluate the capability of the new transgenic oil to restore EPA and DHA levels in farmed salmon to those of a decade ago before the development of sustainable feeds ${ }^{(4)}$. Therefore, feeds were formulated with lower levels of fishmeal (30 v. 49 or $35 \%$ previously) and, in the reference (COM) diet, FO ( $5 v$. $17 \cdot 5$ or $10 \%$ previously) to reflect current feed formulations and $n-3$ LC-PUFA levels. The impacts of diet TCO on fish growth performance and tissue fatty acid composition were assessed, and influences on fish metabolism were determined by investigating gene expression via liver and pyloric caeca (PC) transcriptomic responses. In addition, at the end of the experimental trial, an ex vivo challenge was performed on head kidney monocytes in order to assess potential impacts on the immune response.

\section{Methods \\ Diets and feeding trial}

The feeding trial was carried out at the facilities of the Institute of Marine Research from December 2016 to February 2017. A total of 297 post-smolt Atlantic salmon (initial weight $133 \cdot 0$ (SD 1.6)) were distributed into nine $400 \mathrm{l}^{2}$ flow-through seawater tanks (thirty-three fish/tank) and fed twice daily with one of the three feeds in triplicate for 12 weeks. Fish were fed to satiety to ensure that feed availability did not restrict growth. Water temperature was maintained at $13^{\circ} \mathrm{C}$ throughout the experimental period. The three feeds were formulated to be essentially isonitrogenous and isolipidic and produced by
Table 1. Formulations, analysed proximate compositions and selected fatty acid profiles of the experimental diets

\begin{tabular}{|c|c|c|c|}
\hline & COM & WCO & TCO \\
\hline \multicolumn{4}{|l|}{ Feed ingredients (\%) } \\
\hline Fishmeal & $30 \cdot 00$ & 30.00 & 30.00 \\
\hline Soya protein concentrate (>62\%) & $10 \cdot 00$ & $10 \cdot 00$ & $10 \cdot 00$ \\
\hline Pea protein $(>72 \%)$ & $10 \cdot 00$ & $10 \cdot 00$ & 10.00 \\
\hline Wheat gluten & 5.00 & $5 \cdot 00$ & 5.00 \\
\hline Maize gluten & $5 \cdot 00$ & $5 \cdot 00$ & $5 \cdot 00$ \\
\hline Wheat & $12 \cdot 95$ & $12 \cdot 95$ & 12.95 \\
\hline Fish oil & $5 \cdot 00$ & 0.00 & 0.00 \\
\hline Rapeseed oil & $15 \cdot 00$ & 0.00 & 0.00 \\
\hline Camelina oil (wild-type) & 0.00 & $20 \cdot 00$ & 0.00 \\
\hline Camelina oil (transgenic) & 0.00 & 0.00 & $20 \cdot 00$ \\
\hline Mineral and vitamin premixes & 2.05 & 2.05 & 2.05 \\
\hline Yttrium oxide & 0.05 & 0.05 & 0.05 \\
\hline \multicolumn{4}{|l|}{ Analysed composition } \\
\hline DM (\%) & $92 \cdot 6$ & 93.9 & $92 \cdot 2$ \\
\hline Protein (\%) & $45 \cdot 1$ & $46 \cdot 4$ & $48 \cdot 6$ \\
\hline Lipid (\%) & 23.4 & $19 \cdot 7$ & $18 \cdot 6$ \\
\hline Ash (\%) & $7 \cdot 1$ & $7 \cdot 4$ & $7 \cdot 6$ \\
\hline Energy $(\mathrm{kJ} / \mathrm{g})$ & $23 \cdot 0$ & $22 \cdot 1$ & $22 \cdot 4$ \\
\hline \multicolumn{4}{|l|}{ Analysed fatty acid profile (\%) } \\
\hline $16: 0$ & $9 \cdot 3$ & 8.6 & 9.5 \\
\hline Total SFA* & $14 \cdot 1$ & $14 \cdot 2$ & $19 \cdot 9$ \\
\hline $18: 1 n-9$ & $42 \cdot 4$ & $15 \cdot 8$ & $7 \cdot 8$ \\
\hline Total MUFA† & $54 \cdot 2$ & $35 \cdot 7$ & $18 \cdot 6$ \\
\hline $18: 2 n-6$ & $15 \cdot 7$ & $18 \cdot 2$ & $19 \cdot 8$ \\
\hline $20: 4 n-6$ & 0.2 & 0.2 & $2 \cdot 2$ \\
\hline Total $n-6$ PUFA & $16 \cdot 2$ & $19 \cdot 9$ & 25.9 \\
\hline $18: 3 n-3$ & $6 \cdot 8$ & $22 \cdot 8$ & $8 \cdot 7$ \\
\hline $20: 3 n-3$ & 0.1 & 0.8 & 0.9 \\
\hline $20: 5 n-3$ & $3 \cdot 2$ & $2 \cdot 4$ & $9 \cdot 4$ \\
\hline $22: 5 n-3$ & 0.4 & 0.3 & 3.9 \\
\hline $22: 6 n-3$ & $3 \cdot 7$ & $2 \cdot 7$ & $9 \cdot 0$ \\
\hline Total $n$-3 PUFA§ & $15 \cdot 0$ & $29 \cdot 7$ & $35 \cdot 2$ \\
\hline Total PUFA & 31.7 & $50 \cdot 1$ & 61.5 \\
\hline Total $n$-3 LC-PUFA & 7.5 & 5.5 & 23.9 \\
\hline
\end{tabular}

COM, fish oil/rapeseed oil feed; WCO, wild-type Camelina oil feed; TCO, transgenic Camelina oil feed; LC-PUFA, long-chain PUFA (sum of $20: 4 n-3,20: 5 n-3,22: 5 n-3$, $22: 6 n-3)$.

* Contains $14: 0,18: 0$ and $20: 0$.

† Contains 16:1n-7, 18:1n-7, 20:1n-11, 20:1n-9, 20:1n-6, 22:1n-11 and $22: 1 n-9$. $\ddagger$ Contains $18: 3 n-6,20: 2 n-6,20: 3 n-6$ and $22: 4 n-6$.

$\S$ Contains $18: 4 n-3,20: 3 n-3$ and $20: 4 n-3$.

vacuum coating identical basal extruded pellets with COM, WCO or high EPA + DHA-Camelina oil (TCO) (Table 1). Fatty acid profiles of the constituent oils used in this trial (online Supplementary Table S1) resulted in percentages of both EPA and DHA in diet TCO that were almost 3-fold higher than in the other two dietary treatments (Table 1). The proportions of $n-6$ and total PUFA were also higher in the TCO diet, whereas this feed showed the lowest levels of MUFA. Yttrium oxide $\left(\mathrm{Y}_{2} \mathrm{O}_{3},>99.9 \%\right.$ purity; Strem Chemicals) was added to the feeds as an inert marker in order to determine lipid and fatty acid digestibility. All procedures were approved by the Norwegian Animal Experiment Committee (Forsøksdyrutvalget), experiment ID 8089

\section{Sample collection}

At the end of the feeding trial, thirteen fish/tank were killed by an overdose of metacaine sulphonate $(>150 \mathrm{mg} / \mathrm{l}$, FINQUEL vet.; ScanAqua AS). Fish were measured (weight and length) 
and blood from four fish/tank was collected through the caudal vein using 1-ml heparinised syringes fitted with 20G needles, and whole blood was used for haematocrit determination. Two whole fish per tank were frozen $\left(-20^{\circ} \mathrm{C}\right)$ for biochemical proximate composition analysis, and liver and $\mathrm{PC}$ were collected from four fish/tank and stabilised in RNA Later (Sigma) and frozen at $-20^{\circ} \mathrm{C}$ until further RNA extraction. After sampling, the fish remaining in the tanks continued to be fed the same feeds as before sampling for a further $3 \mathrm{~d}$, at which point faeces were collected and pooled by tank ( $n 3$ ). In brief, fish were killed by an overdose of metacaine sulphonate as above and faecal samples were collected from the hind gut region by gently squeezing the ventral abdominal area ${ }^{(17)}$. Faeces were initially stored at $-20^{\circ} \mathrm{C}$ and freeze-dried before analyses.

\section{Proximate composition}

Feeds were ground and whole fish were pooled per tank (three per dietary treatment) and homogenised before determination of proximate composition according to standard procedures ${ }^{(18)}$. Moisture contents were obtained after drying them in an oven for $24 \mathrm{~h}$ at $110^{\circ} \mathrm{C}$. Ash content was determined after incinerating the samples at a temperature of $600^{\circ} \mathrm{C}$ for $20 \mathrm{~h}$. Crude protein content was measured by determining nitrogen content $(\mathrm{N} \times 6 \cdot 25)$ using automated Kjeldahl analysis (Tecator Kjeltec Auto 1030 analyzer; Foss) and crude lipid determined gravimetically after Soxhlet lipid extraction with petroleum ether (Fisher Scientific) using a Tecator Soxtec system 2050 Auto Extraction apparatus (Foss).

\section{Calculations}

Biometric parameters were estimated as follows: Fulton's condition factor $(k)=100 \times\left(W / L^{3}\right)$, where $W$ is the final weight $(\mathrm{g})$ and $L$ the total length $(\mathrm{cm})$. Specific growth rate $=100 \times$ $\left(\ln W_{\mathrm{o}}-\ln W_{\mathrm{f}}\right) \times \mathrm{D}^{-1}$, where $W_{\mathrm{o}}$ and $W_{\mathrm{f}}$ are the initial and final weights (tanks means, $n 3$ ), respectively, and $\mathrm{D}$ represents the number of feeding days.

\section{Lipid content and fatty acid composition}

Total lipid was extracted from feeds, faeces and whole fish, and flesh, liver, head kidney, midgut and hindgut homogenates prepared from three pooled fish per tank (three per treatment) by homogenising approximately 1-g samples in chloroform-methanol $(2: 1, \mathrm{v} / \mathrm{v})$ using an Ultra-Turrax tissue disrupter (Fisher Scientific), with content determined gravimetrically ${ }^{(19)}$. Fatty acid methyl esters (FAME) were prepared from total lipid by acidcatalysed transesterification at $50^{\circ} \mathrm{C}$ for $16 \mathrm{~h}^{(20)}$, and FAMEextracted and quantified by a GC (AutoSystem XL; Perkin Elmer) with Total Chrom version 6.3.1 software. The GC was equipped with a fused silica capillary column coated with chemically bonded polyethylene glycol (CP-Wax 52CB, $25 \mathrm{~m} \times$ $0.25 \mathrm{~mm}$ internal diameter; Varian), auto-injector $(1 \mu \mathrm{l}$, inlet temperature $250^{\circ} \mathrm{C}$ ) and a flame ionisation detector $\left(280^{\circ} \mathrm{C}\right)$. He was the carrier gas and the oven temperature programme was $90^{\circ} \mathrm{C}$ for $1 \mathrm{~min}$, increased to $150^{\circ} \mathrm{C}$ at $30^{\circ} \mathrm{C} / \mathrm{min}$ and finally raised to $225^{\circ} \mathrm{C}$ at $3^{\circ} \mathrm{C} / \mathrm{min}$ and held for $7 \mathrm{~min}$. Individual methyl esters were identified by comparison with known standards and a wellcharacterised FO, and also by reference to published data ${ }^{(21)}$.

\section{Digestibility calculation}

The apparent digestibility coefficients (ADC) of lipid and selected fatty acids were calculated as follows: $100-$ $\left(100 \times\left(\mathrm{Y}_{2} \mathrm{O}_{3}\right.\right.$ concentration in feed $/ \mathrm{Y}_{2} \mathrm{O}_{3}$ concentration in faeces $) \times$ (lipid or fatty acid concentration in faeces/lipid or fatty acid concentration in feed)). The concentrations of individual fatty acids in diets and faeces were calculated based on the relative proportion of each fatty acid compared with a known amount of internal standard (17:0) added and the total lipid content determined in the samples.

\section{Isolation and primary culture of head kidney monocytes/macrophages}

Four fish per tank were killed by an overdose of metacaine sulphonate (as above) and head kidneys were removed, pooled (two per tank) and transferred to Leibovitz L-15 medium (Sigma) supplemented with $10 \mathrm{U} / \mathrm{ml}$ heparin, $1.8 \mathrm{~mm}$ glucose, $10 \mathrm{~mm}$ HEPES, $20 \mathrm{U}$ Penicillin/ml, $20 \mu \mathrm{g}$ Streptomycin $/ \mathrm{ml}$ and $0.05 \mu \mathrm{g}$ Amphotericin B/ml. Head kidneys were carefully sieved through a $100-\mu \mathrm{m}$ nylon cell strainer, and the cell suspension was loaded onto discontinuous 36/54\% Percoll (GE Healthcare) gradients followed by centrifugation at $400 \mathrm{~g}$ for $30 \mathrm{~min}$ at $4{ }^{\circ} \mathrm{C}$. The interface was collected and washed twice with L-15 medium (without heparin) followed by centrifugation at $400 \boldsymbol{g}$ for $5 \mathrm{~min}$ at $4^{\circ} \mathrm{C}$. Finally, cells were diluted in L-15 medium and seeded at a density of $1 \times 10^{7}$ cells per well in ninety-six-well or six-well culture plates (Nunc) in aliquots of $50 \mu \mathrm{l} /$ well or $1 \mathrm{ml} /$ well, respectively. The culture plates were incubated at $12^{\circ} \mathrm{C}$ overnight and the cells were washed twice in $50 \mathrm{ml}$ of L-15 and incubated in L-15 for further studies.

\section{Lipopolysaccharide challenge}

Isolated macrophage cultures (six-well plates; $n$ 6) were stimulated with $20 \mu \mathrm{g} / \mathrm{ml}$ crude Escherichia coli lipopolysaccharides (LPS) (0111:B4; Sigma-Aldrich). Samples were collected before the addition of LPS $(0 \mathrm{~h})$, and after incubation at $12^{\circ} \mathrm{C}$ for sequential sampling points ( 6 and $24 \mathrm{~h}$ ) cells were harvested by adding $1 \mathrm{ml}$ of TRI Reagent ${ }^{\circledR}$ (Sigma) lysis buffer and stored at $-70^{\circ} \mathrm{C}$ until RNA extraction.

\section{Respiratory burst activity}

Respiratory burst activity was determined by the reduction of nitroblue tetrazolium (NBT) to formazan ${ }^{(22,23)}$. Cells were incubated in L-15 medium supplemented with $1 \mathrm{mg} / \mathrm{ml} \mathrm{NBT}$ and $1 \mu \mathrm{g} / \mathrm{ml}$ phorbol myristate acetate for $30 \mathrm{~min}$ at $12^{\circ} \mathrm{C}$. Cells were then washed twice with pre-warmed PBS and fixed in absolute methanol for $10 \mathrm{~min}$, washed once with $70 \%$ methanol to remove extracellular formazan, air-dried and then intracellular formazan was dissolved in $120 \mu \mathrm{l}$ of $2 \mathrm{~m} \mathrm{KOH}$ and $140 \mu \mathrm{l}$ of dimethyl sulfoxide. 
Absorbance was measured in a microplate reader at $630 \mathrm{~nm}$ using a $\mathrm{KOH} /$ dimethyl sulfoxide blank. The mean number of cells, obtained from at least three wells, was determined by counting nuclei after removal of medium and addition of $100 \mu \mathrm{l}$ of lysis buffer containing $0.1 \mathrm{~m}$ citric acid, $1 \%$ Tween 20 and $0.05 \%$ crystal violet. Results were presented as absorbance per $10^{5}$ cells.

\section{Phagocytosis}

Phagocytic activity was determined by a modification of the method of Pulsford et al. ${ }^{(24)}$ using opsonised yeast as engulfed material. For opsonisation, yeast was sterilised in boiling water and, after several washes with PBS, yeast were incubated overnight with fetal bovine serum at room temperature ${ }^{(25)}$. Head kidney cells were mixed with opsonised yeast to obtain an approximate ratio of 10:1 yeast to kidney cells. Phagocytosis proceeded for $1 \mathrm{~h}$ at $26^{\circ} \mathrm{C}$, and was then terminated by washing with ice-cold PBS. Phagocytosis was evaluated by observation by inverted light microscopy ${ }^{(26)}$. At least 100 cells were counted and phagocytosis was expressed as phagocytosis percentage (PP), which was calculated as follows:

$$
\begin{aligned}
\mathrm{PP}= & \left(\frac{\text { no. of cells ingesting yeasts }}{\text { no. of adherent cells observed }}\right) \\
& \times\left(\frac{\text { no. of yeast ingested }}{\text { no. of adherent cells observed }}\right) .
\end{aligned}
$$

\section{RNA extraction and complementary DNA synthesis}

Individual liver and PC samples from eighteen fish per dietary treatment were homogenised in $1 \mathrm{ml}$ of TriReagent ${ }^{\circledR}$ (SigmaAldrich) to extract total RNA according to the manufacturer's protocol. Quantity and quality of RNA were determined by spectrophometry using a Nanodrop ND-1000 (Labtech Int.). The same protocol was used to extract RNA from macrophage samples. Complementary DNA (cDNA) was synthesised using a high-capacity reverse transcription kit using $2 \mu \mathrm{g}$ of total RNA and random primers in a total reaction volume of $20 \mu \mathrm{l}$ according to the manufacturer's protocol (Applied Biosystems). The samples were pooled to obtain six per dietary treatment. A dilution of 1:20 was applied to the resulting cDNA using milliQ water (Thermo Scientific).

\section{Liver and pyloric caeca transcriptome - microarray hybridisations and image analysis}

Transcriptomic analysis of liver and PC was performed using a custom-designed $4 \times 44 \mathrm{k}$ Atlantic salmon oligo microarray (ArrayExpress accession no. A-MEXP-2065; Agilent Technologies). The salmon microarray and laboratory procedures utilised have been widely used and validated in many previous studies $^{(10-11,27-30)}$. Replicate RNA samples were amplified using TargetAmp ${ }^{\mathrm{TM}}$ 1-Round Aminoallyl-aRNA Amplification Kit (Epicentre Technologies Corporation) according to the recommended procedures. Aminoallyl-amplified RNA (aRNA) samples were labelled with Cy3 dye (GE HealthCare Life Sciences), whereas a pool of all aRNA samples was labelled with Cy5 dye
(GE HealthCare Life Sciences) and used as a common reference in a dual-label common reference design, and finally hybridised. Scanning was performed using a GenePix $4200 \mathrm{AL}$ Scanner (Molecular Devices (UK) Ltd), and the resulting images were analysed with Agilent Feature Extraction Software version 9.5 (Agilent Technologies) to extract intensity values and identify features. Features considered outliers (i.e. defined as those probes whose background intensity was between the 0.05th and 99.95th percentiles of the distribution) in two or more replicates within at least one treatment were excluded from further analyses. In addition, features consistently expressed just above background noise (defined as those features whose intensity was lower than the 5 th percentile of the distribution in $75 \%$ or more of the analysed samples) were also removed. The full protocol for microarray and data analysis has been reported previously ${ }^{(10)}$. The full data set supporting the results is available in MIAME-compliant format in the ArrayExpress repository under accession number E-MTAB-6228.

\section{Quantitative PCR gene expression}

Gene expression levels were determined by real-time quantitative RT-PCR in liver, PC and macrophages as described previously $^{(31)}$. Genes involved in LC-PUFA biosynthesis (delta- 6 fatty acyl desaturase (fads2dO); delta-5 fatty acyl desaturase (fads2d5); fatty acyl elongase 2; fatty acyl elongase 5 isoform a; fatty acyl elongase isoform $b$ (elovl $5 b)$ ) were measured in liver and PC, whereas genes involved in inflammation (il1b;cyclooxygenase 2 (cox2), inducible nitric oxide synthase (inos) and tnfo) and anti-bacterial activity (cathelicidin (cath) and hepcidin) were measured in macrophages (online Supplementary Table S2). Results were normalised using reference genes: cofilin 2, elongation factor 1 alpha and ribosomal protein L2. Primers were designed using Primer 3 in regions that included the microarray probes $^{(32)}$. Quantitative PCR was performed using a Biometra TOptical Thermocycler (Analytik Jena) in ninety-six-well plates in duplicate $20-\mu \mathrm{l}$ reaction volumes containing $10 \mu \mathrm{l}$ of Luminaris Color HiGreen qPCR Master Mix (Thermo Scientific), $1 \mu \mathrm{l}$ of primer corresponding to the analysed gene ( $10 \mathrm{pmol}), 3 \mu \mathrm{l}$ of molecular biology-grade water and $5 \mu \mathrm{l}$ of cDNA, with the exception of the reference genes, which were determined using $2 \mu \mathrm{l}$ of cDNA. In addition, amplifications were carried out with a systematic negative control (NTC-no template control) containing no cDNA. Standard amplification parameters contained an UDG pre-treatment at $50^{\circ} \mathrm{C}$ for $2 \mathrm{~min}$, an initial activation step at $95^{\circ} \mathrm{C}$ for $10 \mathrm{~min}$, followed by thirty-five cycles: $15 \mathrm{~s}$ at $95^{\circ} \mathrm{C}, 30 \mathrm{~s}$ at the annealing $\mathrm{Tm}$ and $30 \mathrm{~s}$ at $72^{\circ} \mathrm{C}$.

\section{Statistical analysis}

All data are means and standard deviations ( $n$ 3) unless otherwise specified. Percentage data were subjected to arcsin square-root transformation before statistical analyses. Data were tested for normality and homogeneity of variances with Levene's test before one-way ANOVA followed by a Tukey post hoc test. All statistical analyses including the gene expression results were performed using SPSS software (IBM SPSS Statistics 23; SPSS Inc.). 


\section{Results}

\section{Fish growth performance and biochemical composition}

No significant differences were observed between the three dietary groups at the end of the feeding period in any of the evaluated growth or biometric parameters (Table 2). There was a $100 \%$ survival rate and no presence of disease was observed. Fish fed diet TCO had a lower lipid content than fish fed the COM and WCO diets, but there were no differences in protein, ash or DM contents of whole fish (Table 2).

\section{Lipid and fatty acid digestibility}

Differences in ADC of dietary lipid were observed among the dietary treatments, with TCO showing the lowest value (Table 3). The ADC of SFA and MUFA varied between about $87-94 \%$ and $91-98 \%$, respectively, with the rank order generally being $\mathrm{COM}>\mathrm{WCO}>\mathrm{TCO}$ (Table 3). The ADC for $n-6, n-3$ and total PUFA were all $97-98 \%$ with few significant differences between feeds, although the diet WCO showed the lowest ADC for EPA, DHA, 22:5n-3 (DPA) and 20:4n-6 (arachidonic acid (ARA)). The COM diet showed the lowest ADC for $20: 3 n-3$, probably reflecting the very low dietary content of this fatty acid (Table 1 ).

\section{Lipid contents and fatty acid compositions of whole fish} and tissues

The lower lipid content of whole fish fed diet TCO compared with fish fed COM (Table 2) was reflected in the lipid content of flesh (whole muscle), although there was no significant difference to fish fed WCO (Table 4). In contrast, diet had no effect on the lipid contents of liver and head kidney (Table 5).

\section{Fatty acid compositions of whole fish and tissues}

The proportion of total $n-3$ LC-PUFA in whole body of Atlantic salmon fed diet TCO was around double that of fish fed diets WCO or COM (Table 4). Specifically, the relative contents of
EPA, DPA and DHA were highest in fish fed TCO, with fish fed COM and WCO showing similar lower values. The proportions of 18:2n-6, ARA and n-6 PUFA were also highest in TCO-fed fish, with COM-fed fish showing the lowest proportions of $18: 2 n-6$ and total $n$ - 6 PUFA. Differences were also observed in total SFA and monoenes, with COM-fed fish showing the lowest and highest contents, respectively.

Table 3. Apparent digestibility coefficients of total lipid and individual fatty acids

(Mean values and standard deviations; $n 3$ )

\begin{tabular}{|c|c|c|c|c|c|c|}
\hline & \multicolumn{2}{|c|}{ COM } & \multicolumn{2}{|c|}{ WCO } & \multicolumn{2}{|c|}{ TCO } \\
\hline & Mean & $\mathrm{SD}$ & Mean & SD & Mean & $\mathrm{SD}$ \\
\hline Total lipid & $94 \cdot 6^{a}$ & 0.3 & $93 \cdot 7^{\mathrm{a}}$ & 0.1 & $90 \cdot 7^{b}$ & 0.7 \\
\hline $14: 0$ & $95 \cdot 9^{a}$ & 0.4 & $95 \cdot 0^{a}$ & 1.6 & $92 \cdot 5^{\mathrm{b}}$ & 0.1 \\
\hline $15: 0$ & $94 \cdot 6^{a}$ & 0.2 & $92 \cdot 7^{\mathrm{a}, \mathrm{b}}$ & $2 \cdot 1$ & $89 \cdot 6^{\mathrm{b}}$ & 0.8 \\
\hline $16: 0$ & $93.9^{a}$ & 0.4 & $92 \cdot 4^{\mathrm{a}, \mathrm{b}}$ & $2 \cdot 3$ & $89 \cdot 7^{b}$ & 0.8 \\
\hline $18: 0$ & $91 \cdot 8^{a}$ & 0.8 & $89 \cdot 6^{a, b}$ & 3.6 & $85 \cdot 1^{b}$ & 1.5 \\
\hline Total SFA & $93 \cdot 7^{a}$ & 0.5 & $91.4^{\mathrm{a}, \mathrm{b}}$ & $2 \cdot 8$ & $86 \cdot 7^{b}$ & $1 \cdot 3$ \\
\hline $16: 1 n-7$ & $97 \cdot 9^{a}$ & 0.5 & $97 \cdot 1^{a, b}$ & 0.9 & $96 \cdot 0^{\mathrm{b}}$ & 0.7 \\
\hline $18: 1 n-9$ & $98 \cdot 1^{a}$ & 0.4 & $96 \cdot 7^{\mathrm{a}}$ & 0.2 & $94 \cdot 4^{b}$ & 1.1 \\
\hline $18: 1 n-7$ & $97 \cdot 7^{a}$ & 0.4 & $95 \cdot 8^{b}$ & 0.2 & $95 \cdot 6^{\mathrm{b}}$ & 0.6 \\
\hline $20: 1 n-9$ & 96.5 & 0.7 & $97 \cdot 0$ & 0.2 & $96 \cdot 0$ & 0.5 \\
\hline $20: 1 n-7$ & 95.4 & 0.7 & 96.5 & 0.2 & 95.0 & 0.6 \\
\hline $22: 1 n-11$ & $96 \cdot 2^{a}$ & 0.7 & $95 \cdot 2^{a}$ & 1.7 & $91 \cdot 1^{\mathrm{b}}$ & 1.9 \\
\hline $22: 1 n-9$ & $96 \cdot 2^{\mathrm{a}}$ & 0.7 & $94 \cdot 9^{a, b}$ & $2 \cdot 4$ & $91 \cdot 5^{\mathrm{b}}$ & 1.2 \\
\hline Total monoenes & $97 \cdot 9^{a}$ & 0.4 & $96 \cdot 4^{a, b}$ & $1 \cdot 2$ & $94 \cdot 6^{\mathrm{b}}$ & 0.6 \\
\hline $18: 2 n-6$ & $97 \cdot 8$ & 0.4 & $97 \cdot 3$ & 0.5 & $97 \cdot 2$ & 0.5 \\
\hline $20: 2 n-6$ & $90 \cdot 6^{\mathrm{b}}$ & 3.4 & $97 \cdot 4^{\mathrm{a}}$ & 0.9 & $92 \cdot 5^{a, b}$ & 1.4 \\
\hline $20: 4 n-6$ & $97 \cdot 2^{a, b}$ & 0.2 & $95 \cdot 0^{b}$ & 0.0 & $99 \cdot 2^{\mathrm{a}}$ & $1 \cdot 1$ \\
\hline Total $n-6$ PUFA & $97 \cdot 7$ & 0.4 & $97 \cdot 2$ & 0.5 & 97.5 & 0.5 \\
\hline $18: 3 n-3$ & $98 \cdot 7$ & 0.3 & $98 \cdot 8$ & 0.3 & $98 \cdot 3$ & 0.3 \\
\hline $18: 4 n-3$ & $98 \cdot 8$ & 0.4 & 97.5 & 0.9 & $99 \cdot 1$ & 0.3 \\
\hline $20: 3 n-3$ & $85 \cdot 7^{b}$ & $5 \cdot 1$ & $97 \cdot 5^{a}$ & 1.0 & $97 \cdot 0^{\mathrm{a}}$ & 0.3 \\
\hline $20: 4 n-3$ & $96 \cdot 1^{a, b}$ & 1.6 & $91 \cdot 7^{b}$ & 2.5 & $98 \cdot 4^{\mathrm{a}}$ & 0.5 \\
\hline $20: 5 n-3$ & $98 \cdot 3^{a}$ & 0.3 & $97 \cdot 0^{\mathrm{b}}$ & 0.4 & $98 \cdot 5^{\mathrm{a}}$ & 0.3 \\
\hline $22: 5 n-3$ & $95 \cdot 4^{\mathrm{b}}$ & 1.0 & $92 \cdot 7^{\mathrm{c}}$ & $1 \cdot 1$ & $98 \cdot 4^{\mathrm{a}}$ & 0.4 \\
\hline $22: 6 n-3$ & $95 \cdot 6^{\mathrm{a}}$ & 0.5 & $92 \cdot 2^{b}$ & 0.7 & $96 \cdot 2^{a}$ & 0.8 \\
\hline Total $n-3$ PUFA & $97 \cdot 7$ & 0.4 & $97 \cdot 9$ & 0.4 & $97 \cdot 9$ & 0.4 \\
\hline Total PUFA & $98 \cdot 3$ & $1 \cdot 3$ & 97.6 & 0.4 & $97 \cdot 7$ & 0.5 \\
\hline
\end{tabular}

COM, fish oil/rapeseed oil feed; WCO, wild-type Camelina oil feed; TCO, transgenic Camelina oil feed.

a,b,c Mean values with unlike superscript letters were statistically significantly different between the treatments as determined by one-way ANOVA with Tukey's post hoc test $(P<0.05)$.

Table 2. Growth performance, biometric parameters and biochemical composition of whole fish after feeding the experimental diets for 12 weeks (Mean values and standard deviations; $n 3$ )

\begin{tabular}{|c|c|c|c|c|c|c|c|}
\hline & \multicolumn{2}{|c|}{ COM } & \multicolumn{2}{|c|}{ WCO } & \multicolumn{2}{|c|}{$\mathrm{TCO}$} & \multirow[b]{2}{*}{$P$} \\
\hline & Mean & SD & Mean & SD & Mean & SD & \\
\hline Final weight $(\mathrm{g})$ & $412 \cdot 2$ & $5 \cdot 6$ & $397 \cdot 7$ & $9 \cdot 2$ & $406 \cdot 2$ & $18 \cdot 2$ & 0.447 \\
\hline Length (cm) & 31.4 & 0.3 & $31 \cdot 2$ & 0.2 & 31.6 & 0.5 & 0.400 \\
\hline Gutted (g) & $367 \cdot 1$ & 14.4 & 349.5 & $15 \cdot 2$ & $365 \cdot 2$ & $17 \cdot 6$ & 0.388 \\
\hline $\mathrm{HSI}$ & 1.0 & 0.0 & $1 \cdot 0$ & 0.0 & $1 \cdot 0$ & 0.1 & 0.856 \\
\hline VSI & $6 \cdot 2$ & 0.2 & $6 \cdot 1$ & 0.2 & 5.9 & 0.2 & 0.177 \\
\hline Haematocrit & $33 \cdot 7$ & 0.6 & $32 \cdot 4$ & 0.8 & 33.9 & 0.8 & 0.231 \\
\hline \multicolumn{8}{|c|}{ Whole body composition (\% wet weight) } \\
\hline Crude protein & $17 \cdot 9$ & 0.3 & $18 \cdot 2$ & $0 \cdot 2$ & $18 \cdot 0$ & 0.6 & 0.640 \\
\hline Crude lipid & $11 \cdot 7^{\mathrm{a}}$ & 0.5 & $10 \cdot 9^{a}$ & 0.3 & $9 \cdot 8^{\mathrm{b}}$ & 0.2 & 0.013 \\
\hline Ash & 1.6 & 0.0 & 1.6 & 0.0 & $1 \cdot 7$ & 0.0 & 0.178 \\
\hline DM & 31.5 & 0.2 & $32 \cdot 3$ & 0.6 & $31 \cdot 0$ & 0.5 & 0.270 \\
\hline
\end{tabular}

COM, fish oil/rapeseed oil feed; WCO, diet containing wild-type Camelina; TCO, transgenic Camelina oil feed; HSI, hepato-somatic index; VSI, viscero-somatic index.

a,b Mean values with unlike superscript letters were statistically significantly different between the treatments as determined by one-way ANOVA with Tukey's post hoc test $(P<0.05)$. 
Table 4. Lipid contents (percentage of wet weight) and fatty acid compositions (percentage of total fatty acids) of total lipid of whole body and flesh (muscle) of Atlantic salmon after feeding the experimental diets for 12 weeks

(Mean values and standard deviations; $n 3$ )

\begin{tabular}{|c|c|c|c|c|c|c|}
\hline & \multicolumn{2}{|c|}{ COM } & \multicolumn{2}{|c|}{ WCO } & \multicolumn{2}{|c|}{ TCO } \\
\hline & Mean & SD & Mean & SD & Mean & SD \\
\hline \multicolumn{7}{|l|}{ Whole body } \\
\hline Lipid content & $11 \cdot 7^{\mathrm{a}}$ & 0.5 & $10 \cdot 9^{a}$ & 0.3 & $9 \cdot 8^{\mathrm{b}}$ & 0.2 \\
\hline $16: 0$ & $10 \cdot 6$ & 0.3 & $10 \cdot 9$ & 0.1 & 11.0 & 0.1 \\
\hline Total SFA* & $16 \cdot 1^{\mathrm{C}}$ & 0.3 & $17 \cdot 1^{\mathrm{b}}$ & 0.2 & $19 \cdot 1^{\mathrm{a}}$ & 0.3 \\
\hline $18: 1 n-9$ & $38 \cdot 6^{\mathrm{a}}$ & 0.7 & $22 \cdot 9^{b}$ & 0.3 & $18 \cdot 5^{\mathrm{C}}$ & 0.9 \\
\hline Total monoenes $†$ & $52 \cdot 3^{\mathrm{a}}$ & 0.6 & $40 \cdot 3^{b}$ & 0.2 & $31 \cdot 2^{\mathrm{C}}$ & 0.8 \\
\hline $18: 2 n-6$ & $13 \cdot 1^{c}$ & 0.2 & $14.4^{\mathrm{b}}$ & 0.1 & $16 \cdot 1^{\mathrm{a}}$ & 0.5 \\
\hline $20: 4 n-6$ & $0.3^{b}$ & 0.0 & $0.3^{\mathrm{b}}$ & 0.0 & $1 \cdot 2^{\mathrm{a}}$ & 0.2 \\
\hline Total $n-6$ PUFA & $15 \cdot 1^{\mathrm{C}}$ & 0.2 & $17 \cdot 0^{\mathrm{b}}$ & 0.0 & $21 \cdot 1^{\mathrm{a}}$ & 0.2 \\
\hline $18: 3 n-3$ & $4.9^{c}$ & 0.1 & $13 \cdot 2^{\mathrm{a}}$ & 0.2 & $6 \cdot 5^{\mathrm{b}}$ & 0.1 \\
\hline $20: 5 n-3$ & $2 \cdot 2^{b}$ & 0.2 & $2 \cdot 1^{\mathrm{b}}$ & 0.1 & $5 \cdot 2^{\mathrm{a}}$ & 0.3 \\
\hline $22: 5 n-3$ & $0.9^{b}$ & 0.1 & $0.8^{\mathrm{b}}$ & 0.0 & $3 \cdot 1^{\mathrm{a}}$ & 0.1 \\
\hline $22: 6 n-3$ & $6 \cdot 4^{b}$ & 0.6 & $5 \cdot 7^{\mathrm{b}}$ & 0.0 & $10 \cdot 1^{\mathrm{a}}$ & 0.3 \\
\hline Total $n-3$ PUFA§ & $16 \cdot 2^{c}$ & 0.9 & $25 \cdot 3^{\mathrm{b}}$ & 0.0 & $28 \cdot 3^{\mathrm{a}}$ & 0.7 \\
\hline$E P A+D H A$ & $8.5^{b}$ & 0.8 & $7 \cdot 8^{\mathrm{b}}$ & 0.1 & $15 \cdot 3^{\mathrm{a}}$ & 0.6 \\
\hline Total $n$-3 LC-PUFA & $8 \cdot 7$ & $1 \cdot 2$ & $8 \cdot 7$ & 1.6 & $11 \cdot 2$ & 1.5 \\
\hline \multicolumn{7}{|l|}{ Flesh } \\
\hline Lipid content & $3.9^{\mathrm{a}}$ & 1.5 & $2 \cdot 6^{\mathrm{a}, \mathrm{b}}$ & 0.5 & $2 \cdot 5^{\mathrm{b}}$ & 0.6 \\
\hline $16: 0$ & 11.7 & 0.8 & 11.7 & 0.3 & $12 \cdot 1$ & 0.5 \\
\hline Total saturated ${ }^{*}$ & $17 \cdot 2^{\mathrm{b}}$ & 1.0 & $17 \cdot 6^{\mathrm{b}}$ & 0.2 & $19 \cdot 7^{\mathrm{a}}$ & 0.4 \\
\hline $18: 1 n-9$ & $34 \cdot 6^{\mathrm{a}}$ & 1.9 & $19 \cdot 1^{\mathrm{b}}$ & 1.3 & $14 \cdot 7^{\mathrm{C}}$ & 2.0 \\
\hline Total monoenes $†$ & $46.0^{\mathrm{a}}$ & 2.5 & $33.4^{\mathrm{b}}$ & 1.8 & $24 \cdot 6^{c}$ & 3.3 \\
\hline $18: 2 n-6$ & $12 \cdot 2^{\mathrm{b}}$ & 0.6 & $12 \cdot 8^{\mathrm{b}}$ & 0.3 & $13 \cdot 7^{\mathrm{a}}$ & 0.4 \\
\hline $20: 4 n-6$ & $0.5^{\mathrm{b}}$ & 0.1 & $0.5^{\mathrm{b}}$ & 0.1 & $1 \cdot 7^{\mathrm{a}}$ & 0.2 \\
\hline Total $n-6$ PUFA & $14 \cdot 2^{\mathrm{b}}$ & 0.6 & $15 \cdot 3^{\mathrm{b}}$ & 0.2 & $18 \cdot 2^{\mathrm{a}}$ & 0.5 \\
\hline $18: 3 n-3$ & $5 \cdot 0^{c}$ & 0.2 & $12 \cdot 7^{\mathrm{a}}$ & 0.4 & $6 \cdot 3^{b}$ & 0.4 \\
\hline $20: 5 n-3$ & $2.9^{b}$ & 0.5 & $3 \cdot 3^{\mathrm{b}}$ & 0.4 & $6 \cdot 5^{a}$ & 0.8 \\
\hline $22: 5 n-3$ & $1 \cdot 1^{\mathrm{b}}$ & 0.1 & $1 \cdot 1^{\mathrm{b}}$ & 0.1 & $3.5^{\mathrm{a}}$ & 0.3 \\
\hline $22: 6 n-3$ & $10 \cdot 2^{b}$ & 0.6 & $12 \cdot 4^{\mathrm{b}}$ & 0.8 & $17 \cdot 7^{\mathrm{a}}$ & 2.0 \\
\hline Total $n-3$ PUFA§ & $22 \cdot 6^{b}$ & $2 \cdot 2$ & $33 \cdot 8^{\mathrm{a}}$ & 1.9 & $37 \cdot 6^{\mathrm{a}}$ & 3.0 \\
\hline$E P A+D H A$ & $13 \cdot 1^{\mathrm{b}}$ & $2 \cdot 2$ & $15 \cdot 6^{\mathrm{b}}$ & 1.6 & $24 \cdot 2^{\mathrm{a}}$ & 2.6 \\
\hline Total $n$-3 LC-PUFA & $16 \cdot 5^{\mathrm{b}}$ & 0.8 & $18 \cdot 7^{\mathrm{b}}$ & 0.6 & $29 \cdot 3^{a}$ & 0.8 \\
\hline
\end{tabular}

COM, fish oil/rapeseed oil feed; WCO, wild-type Camelina oil feed; TCO, transgenic Camelina oil feed; LC- PUFA, long-chain PUFA (sum of $20: 4 n-3,20: 5 n-322: 5 n-3$ and $22: 6 n-3$ )

${ }^{a, b, c}$ Mean values with unlike superscript letters within a row were significantly different among diets as determined by one-way ANOVA with Tukey's comparison test $(P<0.05)$.

* Contains $14: 0,15: 0,18: 0,20: 0$ and $22: 0$

† Contains 16:1n-7, 18:1n-7, 20:1n-9, 22:1n-11, 22:1n-9 and $24: 1$.

$\ddagger$ Contains $20: 2 n-6$ and $20: 3 n-6$

$\S$ Contains $18: 4 n-3,20: 3 n-3$ and $20: 4 n-3$.

Flesh of fish fed TCO displayed the highest contents of the $n$-3 LC-PUFA, EPA, DPA and DHA, and ARA (Table 4). In COMfed fish, flesh showed the highest proportions of total saturates and $18: 1 n-9$, and the lowest contents of $18: 3 n-3$, whereas WCO-fed fish contained the highest percentage of this fatty acid. Relative levels of total $n-3$ PUFA, EPA and DPA in liver and head kidney were highest in fish fed TCO, although total $n$-3 LC-PUFA levels in TCO-fed fish were not different from those of WCO-fed fish. Although DHA level was highest in fish fed TCO in both liver and head kidney, variation in the data rendered the dietary differences not significant (Table 5).

A PCA analysis was applied to the whole fish and tissue fatty acid profiles (percentage) of fish fed the three experimental feeds. The first two principal components explained $82.8 \%$ of variance (Fig. 1). The score plot showed some separation between tissues of fish fed COM and those fed both WCO and
Table 5. Lipid contents (percentage of wet weight) and fatty acid compositions (percentage of total fatty acids) of total lipid of liver and head kidney of Atlantic salmon after feeding the experimental diets for 12 weeks (Mean values and standard deviations; $n 3$ )

\begin{tabular}{|c|c|c|c|c|c|c|}
\hline & \multicolumn{2}{|c|}{ COM } & \multicolumn{2}{|c|}{ WCO } & \multicolumn{2}{|c|}{ TCO } \\
\hline & Mean & SD & Mean & SD & Mean & SD \\
\hline \multicolumn{7}{|l|}{ Liver } \\
\hline Lipid content & 4.7 & 1.0 & 4.4 & 0.9 & $4 \cdot 1$ & 0.5 \\
\hline $16: 0$ & $13 \cdot 2$ & 1.7 & 14.0 & 1.4 & $15 \cdot 0$ & 0.9 \\
\hline Total SFA* & $19 \cdot 3^{b}$ & 1.9 & $20 \cdot 4^{a, b}$ & 1.3 & $23 \cdot 5^{\mathrm{a}}$ & 1.0 \\
\hline $18: 1 n-9$ & $24.9^{a}$ & 5.5 & $15 \cdot 7^{\mathrm{b}}$ & 2.5 & $10 \cdot 4^{\mathrm{b}}$ & 0.5 \\
\hline Total monoenes $\dagger$ & $32 \cdot 8^{\mathrm{a}}$ & 6.4 & $24 \cdot 3^{a, b}$ & $3 \cdot 8$ & $16 \cdot 1^{\mathrm{b}}$ & 1.0 \\
\hline $18: 2 n-6$ & 8.5 & 1.0 & $9 \cdot 1$ & 0.9 & 7.6 & 0.5 \\
\hline $20: 4 n-6$ & $2.5^{\mathrm{b}}$ & 0.5 & $2 \cdot 3^{\mathrm{b}}$ & 0.3 & $6 \cdot 3^{\mathrm{a}}$ & 0.0 \\
\hline Total $n-6$ PUFA $\ddagger$ & $14.0^{\mathrm{b}}$ & 0.3 & $15 \cdot 0^{\mathrm{b}}$ & 0.7 & $17 \cdot 3^{\mathrm{a}}$ & 0.4 \\
\hline $18: 3 n-3$ & $2 \cdot 6^{\mathrm{b}}$ & 0.2 & $6 \cdot 7^{\mathrm{a}}$ & $1 \cdot 1$ & $3 \cdot 1^{\mathrm{b}}$ & 0.5 \\
\hline $20: 5 n-3$ & $5 \cdot 5^{\mathrm{b}}$ & 0.7 & $6 \cdot 4^{\mathrm{b}}$ & 0.9 & $8 \cdot 2^{\mathrm{a}}$ & 0.6 \\
\hline $22: 5 n-3$ & $1.6^{\mathrm{b}}$ & 0.2 & $1.6^{\mathrm{b}}$ & 0.3 & $3 \cdot 5^{\mathrm{a}}$ & 0.4 \\
\hline $22: 6 n-3$ & $22 \cdot 8$ & 4.5 & $22 \cdot 2$ & 3.3 & $26 \cdot 2$ & 1.2 \\
\hline Total $n-3$ PUFA§ & $33.9^{\mathrm{b}}$ & $5 \cdot 0$ & $40 \cdot 3^{a, b}$ & 2.9 & $43 \cdot 1^{a}$ & 0.6 \\
\hline$E P A+D H A$ & 28.4 & $5 \cdot 1$ & 28.5 & 3.7 & 34.4 & 1.0 \\
\hline Total $n$-3 LC-PUFA & $30.8^{\mathrm{b}}$ & $2 \cdot 1$ & $31 \cdot 8^{\mathrm{a}, \mathrm{b}}$ & 1.4 & $39 \cdot 1^{\mathrm{a}}$ & 0.5 \\
\hline \multicolumn{7}{|l|}{ Head kidney } \\
\hline Lipid content & 5.6 & $1 \cdot 1$ & 4.2 & 0.4 & $4 \cdot 1$ & 1.0 \\
\hline $16: 0$ & $12 \cdot 6$ & 0.4 & 14.0 & 1.0 & 14.4 & 1.6 \\
\hline Total SFA* & $18 \cdot 1^{\mathrm{b}}$ & 0.6 & $20 \cdot 0^{\mathrm{a}, \mathrm{b}}$ & $1 \cdot 1$ & $22 \cdot 3^{\mathrm{a}}$ & $2 \cdot 1$ \\
\hline $18: 1 n-9$ & $32 \cdot 2^{\mathrm{a}}$ & $2 \cdot 2$ & $18 \cdot 8^{\mathrm{b}}$ & 1.3 & $14 \cdot 2^{b}$ & $2 \cdot 1$ \\
\hline Total monoenes $\dagger$ & $43 \cdot 7^{a}$ & 2.5 & $32 \cdot 0^{\mathrm{b}}$ & 1.8 & $23 \cdot 4^{\mathrm{C}}$ & $2 \cdot 8$ \\
\hline $18: 2 n-6$ & 11.3 & 0.4 & $11 \cdot 8$ & 1.0 & 11.9 & 1.6 \\
\hline $20: 4 n-6$ & $1.0^{\mathrm{b}}$ & 0.2 & $1.3^{\mathrm{b}}$ & 0.3 & $4 \cdot 2^{a}$ & 1.1 \\
\hline Total $n-6$ PUFA & $13 \cdot 7^{\mathrm{b}}$ & 0.4 & $14.9^{\mathrm{b}}$ & $1 \cdot 1$ & $18 \cdot 4^{\mathrm{a}}$ & 0.6 \\
\hline $18: 3 n-3$ & $4 \cdot 2^{b}$ & 0.1 & $10 \cdot 3^{\mathrm{a}}$ & 1.5 & $4 \cdot 9^{\mathrm{b}}$ & 0.7 \\
\hline $20: 5 n-3$ & $4 \cdot 0^{b}$ & 0.5 & $4 \cdot 8^{b}$ & 1.3 & $7 \cdot 1^{\mathrm{a}}$ & 0.5 \\
\hline $22: 5 n-3$ & $1.1^{\mathrm{b}}$ & 0.2 & $1.0^{\mathrm{b}}$ & 0.1 & $2 \cdot 8^{\mathrm{a}}$ & 0.2 \\
\hline $22: 6 n-3$ & 11.6 & 1.5 & $13 \cdot 2$ & $2 \cdot 0$ & $16 \cdot 5$ & $2 \cdot 7$ \\
\hline Total $n$-3 PUFA§ & $22 \cdot 8^{b}$ & $2 \cdot 1$ & $32 \cdot 6^{a}$ & 1.8 & $34 \cdot 1^{a}$ & $2 \cdot 2$ \\
\hline$E P A+D H A$ & $15 \cdot 7^{b}$ & 2.0 & $18 \cdot 1^{\mathrm{a}, \mathrm{b}}$ & 3.3 & $23 \cdot 6^{\mathrm{a}}$ & 3.2 \\
\hline Total $n$-3 LC-PUFA & $17 \cdot 5^{\mathrm{b}}$ & 0.6 & $20 \cdot 2^{\mathrm{b}}$ & 1.0 & $27 \cdot 7^{\mathrm{a}}$ & 1.2 \\
\hline
\end{tabular}

COM, fish oil/rapeseed oil feed; WCO, wild-type Camelina oil feed; TCO, transgenic Camelina oil feed; LC-PUFA, long-chain PUFA (sum of $20: 4 n-3,20: 5 n-3,22: 5 n-3$ and $22: 6 n-3)$.

a,b,c Mean values with unlike superscript letters within a row were significantly different among diets as determined by one-way ANOVA with Tukey's comparison test $(P<0.05)$.

* Contains $14: 0,15: 0,18: 0,20: 0$ and $22: 0$

† Contains $16: 1 n-7,18: 1 n-7,20: 1 n-9,22: 1 n-11,22: 1 n-9$ and $24: 1$.

‡ Contains $20: 2 n-6$ and $20: 3 n-6$.

$\S$ Contains $18: 4 n-3,20: 3 n-3$ and $20: 4 n-3$.

TCO. There was an overlap between tissues of fish fed WCO and TCO, although liver from fish fed TCO showed a distinct profile, clustering at the left side of the plot (red diamonds). The fatty acid vectors representing the MUFA $16: 1 n-7,18: 1 n-7$, $18: 1 n-9$ and $22: 1 n-11$ appeared to be correlated with fish fed the COM diet. The $n-6$ and $n-3$ PUFA $(18: 2 n-6,18: 3 n-3$ and $18: 4 n-3)$ vectors lie towards fish fed WCO, whereas the $n-6$ and $n$-3 LC-PUFA (20:4n-6, $20: 5 n-3$ and $22: 6 n-3)$ point towards TCO-fed fish, as well as livers from WCO-fed fish.

\section{Liver transcriptome}

In liver, a total of 312 unique genes were differentially expressed $(P<0 \cdot 05$; fold-change $(\mathrm{FC})>1 \cdot 3)$ in salmon fed the TCO diet $\mathrm{v}$. the COM diet, whereas 249 genes were affected when comparing WCO-fed fish with COM-fed fish (Table 6). The highest number 


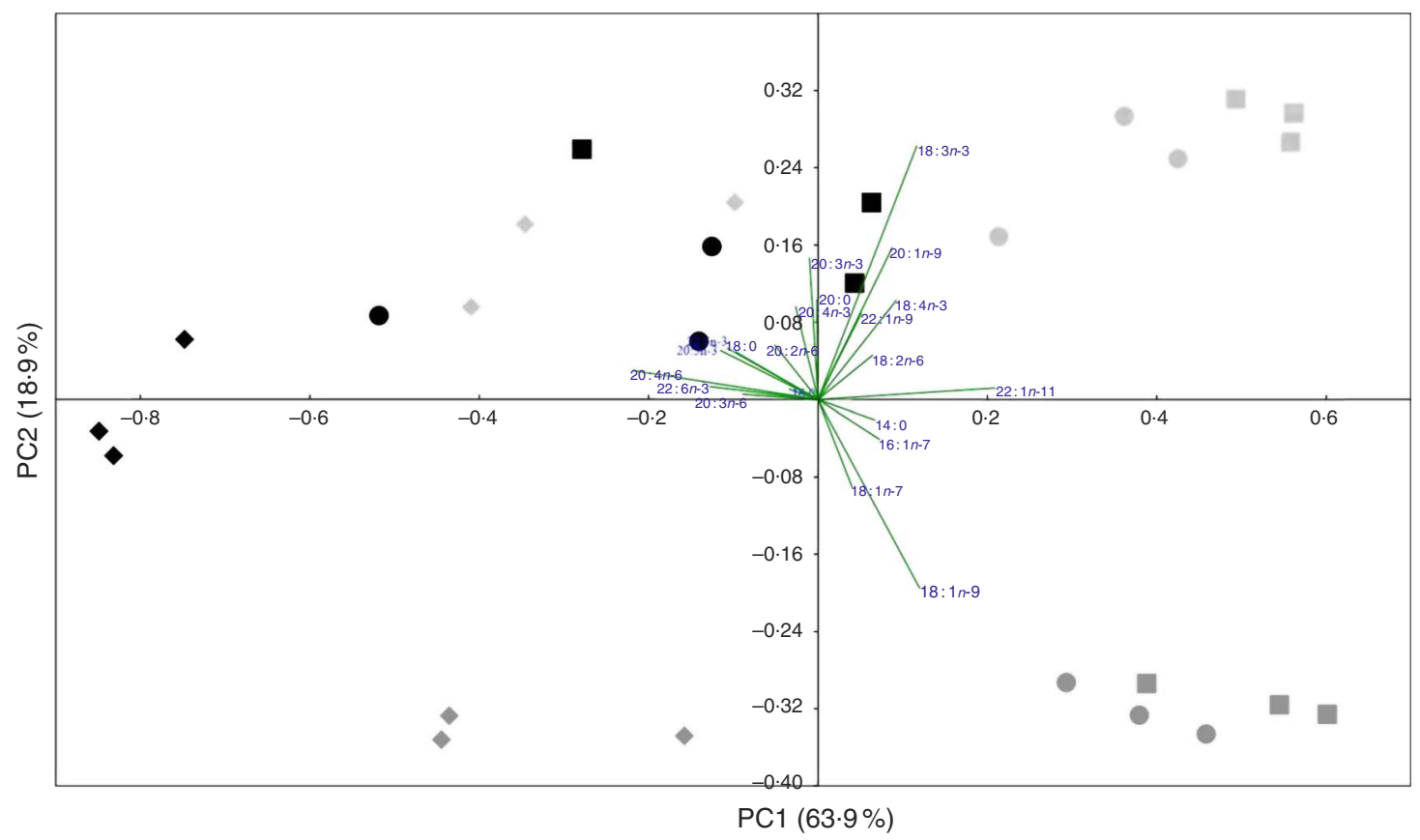

Fig. 1. Principal component analysis (PCA) of fatty acid profiles (percentage of total fatty acids) of tissues from Atlantic salmon fed the experimental feeds for 12 weeks. $\square$ and $\diamond$, Fish fed fish/rapeseed oil; $\bigcirc, \square$ and $\diamond$, fish fed wild-type Camelina oil; $\bigcirc, \quad$ and $\diamond$, fish fed transgenic Camelina oil; $\bullet$ and $\bigcirc$, head kidney; $\boldsymbol{\square}$, and $\ldots$, flesh; $\diamond$ and $\diamond$, liver.

Table 6. Summary of liver and pyloric caeca microarray analysis after removing duplicated probes (Numbers and percentages)

\begin{tabular}{|c|c|c|c|c|c|c|}
\hline & \multicolumn{2}{|c|}{ COM/wCO } & \multicolumn{2}{|c|}{$\mathrm{COM} / \mathrm{TCO}$} & \multicolumn{2}{|c|}{ TCO/WCO } \\
\hline & $n$ & $\%$ & $n$ & $\%$ & $n$ & $\%$ \\
\hline \multicolumn{7}{|l|}{ Liver } \\
\hline Total no. of probes & \multicolumn{6}{|c|}{44000} \\
\hline Total no. of DEG & \multirow{2}{*}{\multicolumn{2}{|c|}{$\begin{array}{l}249 \\
169\end{array}$}} & \multicolumn{2}{|c|}{312} & \multicolumn{2}{|c|}{506} \\
\hline Up-regulated genes & & & \multicolumn{2}{|c|}{262} & \multicolumn{2}{|c|}{89} \\
\hline FC $1.3-1.5$ & 58 & 34.5 & 75 & 28.6 & 25 & $28 \cdot 1$ \\
\hline FC $1.5-2.5$ & 88 & 52.4 & 139 & $53 \cdot 1$ & 50 & $56 \cdot 2$ \\
\hline $\mathrm{FC}>2.5$ & 22 & $13 \cdot 1$ & 48 & $18 \cdot 3$ & 14 & $15 \cdot 7$ \\
\hline Down-regulated genes & \multicolumn{2}{|c|}{80} & \multicolumn{2}{|c|}{50} & \multicolumn{2}{|c|}{417} \\
\hline FC $1.3-1.5$ & 23 & $28 \cdot 7$ & 18 & 36 & 157 & 37.6 \\
\hline FC $1.5-2.5$ & 48 & 60 & 28 & 56 & 211 & $50 \cdot 6$ \\
\hline $\mathrm{FC}>2.5$ & 9 & $11 \cdot 3$ & 4 & 8 & 49 & $11 \cdot 8$ \\
\hline \multicolumn{7}{|l|}{ Pyloric caeca } \\
\hline Total no. of probes & \multicolumn{6}{|c|}{44000} \\
\hline Total no. of DEG & \multirow{2}{*}{\multicolumn{2}{|c|}{$\begin{array}{l}971 \\
918\end{array}$}} & \multirow{2}{*}{\multicolumn{2}{|c|}{$\begin{array}{l}804 \\
729\end{array}$}} & \multicolumn{2}{|c|}{279} \\
\hline Up-regulated genes & & & & & \multicolumn{2}{|c|}{182} \\
\hline FC $1.3-1.5$ & 518 & $56 \cdot 4$ & 421 & $57 \cdot 8$ & 55 & $30 \cdot 1$ \\
\hline FC $1.5-2.5$ & 263 & $28 \cdot 6$ & 207 & 28.4 & 62 & 33.9 \\
\hline $\mathrm{FC}>2.5$ & 137 & 14.9 & 101 & 13.9 & 66 & $36 \cdot 1$ \\
\hline Down-regulated genes & \multicolumn{2}{|c|}{53} & \multicolumn{2}{|c|}{75} & \multicolumn{2}{|c|}{97} \\
\hline FC $1.3-1.5$ & 5 & 9.4 & 14 & $19 \cdot 8$ & 20 & $20 \cdot 6$ \\
\hline FC $1.5-2.5$ & 24 & $45 \cdot 3$ & 29 & $39 \cdot 2$ & 37 & $38 \cdot 1$ \\
\hline $\mathrm{FC}>2.5$ & 24 & $45 \cdot 3$ & 31 & 41.9 & 40 & $41 \cdot 2$ \\
\hline
\end{tabular}

COM, fish oil/rapeseed oil feed; WCO, wild-type Camelina oil feed; TCO, transgenic Camelina oil feed; DEG, differently expressed gene; FC, fold-change.

(506) of differentially expressed genes (DEG) was observed when comparing the hepatic transcriptomes of TCO-fed and WCO-fed fish. Among these unique probes, eighty-six DEG were commonly regulated when comparing fish fed TCO with fish fed either COM or WCO, whereas forty-five were found when TCO- and WCO-fed fish were compared with COM-fed fish and only thirty-seven when fish fed TCO and COM were compared with those fed WCO (Fig. 2(a)).

To elucidate the genes exclusively affected by TCO, KEGG Orthology numbers were assigned to the 86 genes commonly affected by TCO (online Supplementary Table S3), and genes mapped to a known compendium of metabolic pathways (KEGG). 
Enrichr, an integrative web-based software application ${ }^{(33)}$, was used to build a network with the enriched gene sets (Fig. 3(a)). Many of the categories represented belonged to metabolism with high representation of lipid metabolism including 'fatty acid degradation', 'sphingolipid metabolism' and 'terpenoid backbone biosynthesis', as well as amino acid metabolism including 'alanine, aspartate and glutamate metabolism' and 'other glycan degradation'. Genes belonging to other categories such as 'protein processing in the endoplasmic reticulum' and 'DNA replication' were also highly represented. At a gene level, all the genes presented the same direction of regulation (up or down) between both contrasts and a similar FC. Expression of a set of candidate LC-PUFA biosynthesis genes was determined by qPCR with fads $2 d 5$ and fads $2 d 6$ showing up-regulation in fish fed WCO, with no difference between fish fed TCO and COM (Fig. 4). No differences were observed among the expression of the other LC-PUFA biosynthesis genes evaluated by qPCR.

\section{Pyloric caeca transcriptome}

A greater number of DEG was found in PC compared with liver when comparing fish fed either diets TCO or WCO with fish fed COM (804 and 971 DEG, respectively) (Table 6). However when comparing fish fed TCO with fish fed WCO, the number (a)

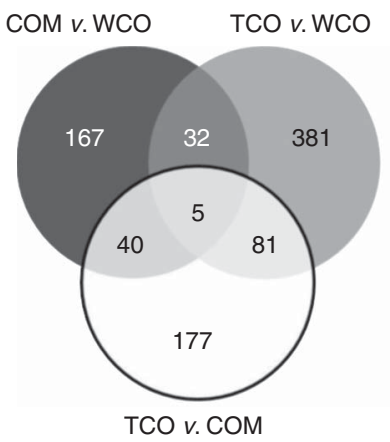

(b)

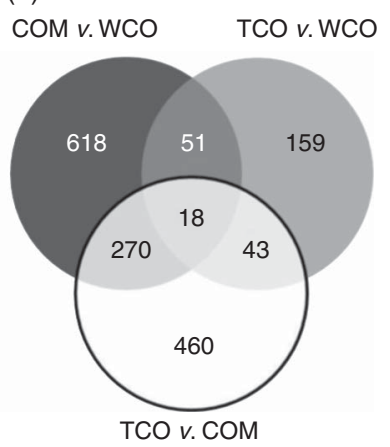

Fig. 2. Venn diagram representing genes differentially expressed in liver (a) and pyloric caeca (b) of Atlantic salmon fed the experimental diets (Welch $t$ test; $P<0.05$, fold-change $>1.3$ ). Non-annotated genes and features corresponding to the same gene are not represented. COM, fish/rapeseed oil feed; TCO, transgenic Camelina oil feed; WCO, wild-type Camelina oil feed. of DEG was much lower in PC compared with liver (279 v. 506). There were differences in the distribution of genes depending on FC, with a high number of DEG showing FC $>2 \cdot 5$, particularly among down-regulated genes.

Only sixty-one genes were commonly regulated in the PC of fish fed TCO compared with fish fed COM and WCO (Fig. 2(b)). Network analysis of the enriched categories showed that most of the genes were related to metabolism, although many also belonged to 'mTOR signalling pathway' and 'regulation of autophagy' (Fig. 3(b)). After removing non-annotated genes, twenty-four unique genes could be identified as being commonly affected by TCO in PC (online Supplementary Table S4). All the genes presented the same direction of regulation and similar FC in both contrasts (TCO $v$. COM and TCO $v$. WCO). High FC were observed particularly in genes related to carbohydrate metabolism ( $N$-acetylgalactosaminide alpha-2,6-sialyltransferase and $\beta$-mannosidase), which were up-regulated in TCO-fed fish, particularly when compared with WCO-fed fish (FC of 12.7 and 6.8, respectively). In PC, although there appeared to be a trend for lower expression of most of the LCPUFA biosynthesis genes in fish fed TCO compared with fish fed COM, this was only significant with elovl5b (Fig. 5).

\section{Head kidney cell lipopolysaccharide challenge and gene expression}

Diet did not significantly affect leucocyte respiratory burst activity, although there was a trend towards lower values in TCO-fed fish ( $P=0.057$; Table 7$)$. Similarly, no differences were observed in phagocytic activity of monocytes/macrophages from fish fed the three dietary treatments $(P=0 \cdot 854$; Table 7$)$.

Atlantic salmon monocytes were exposed to LPS to study the effect on gene expression at 0,6 and $24 \mathrm{~h}$ after addition. The exposure to LPS triggered a response in all of the genes evaluated, with highest expression levels observed $24 \mathrm{~h}$ after application of the challenge (Fig. 6). The FC varied among the studied genes, with the strongest regulation in cox2 (approximately 2500 FC) and the lowest in inos (approximately 4 FC). Two-way ANOVA showed that gene expression was highly affected by sampling time $(P<0 \cdot 001)$, but diet did not affect expression of any of the studied genes and there was no interaction between diet and sample time.

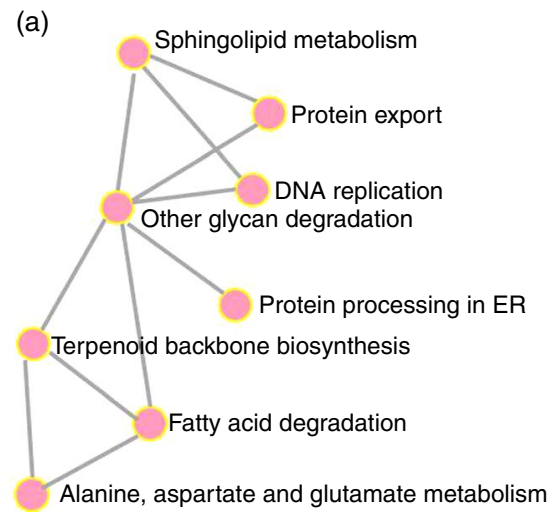

(b)

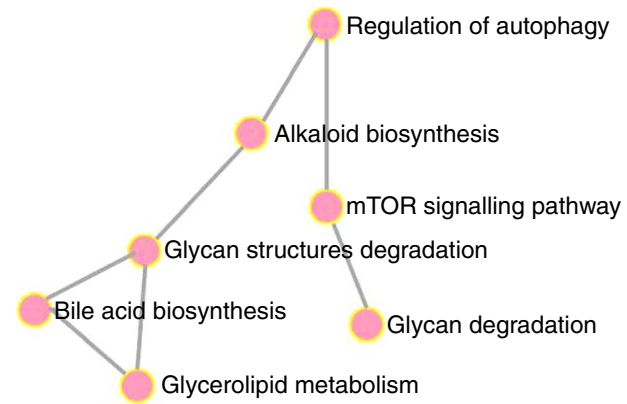

Fig. 3. Metabolic categories enriched with genes commonly regulated in fish fed transgenic Camelina oil. Gene networks in liver (a) and pyloric caeca (b) were produced using the Enrichr web application. ER, endoplasmic reticulum; mTOR, mammalian target of rapamycin. 

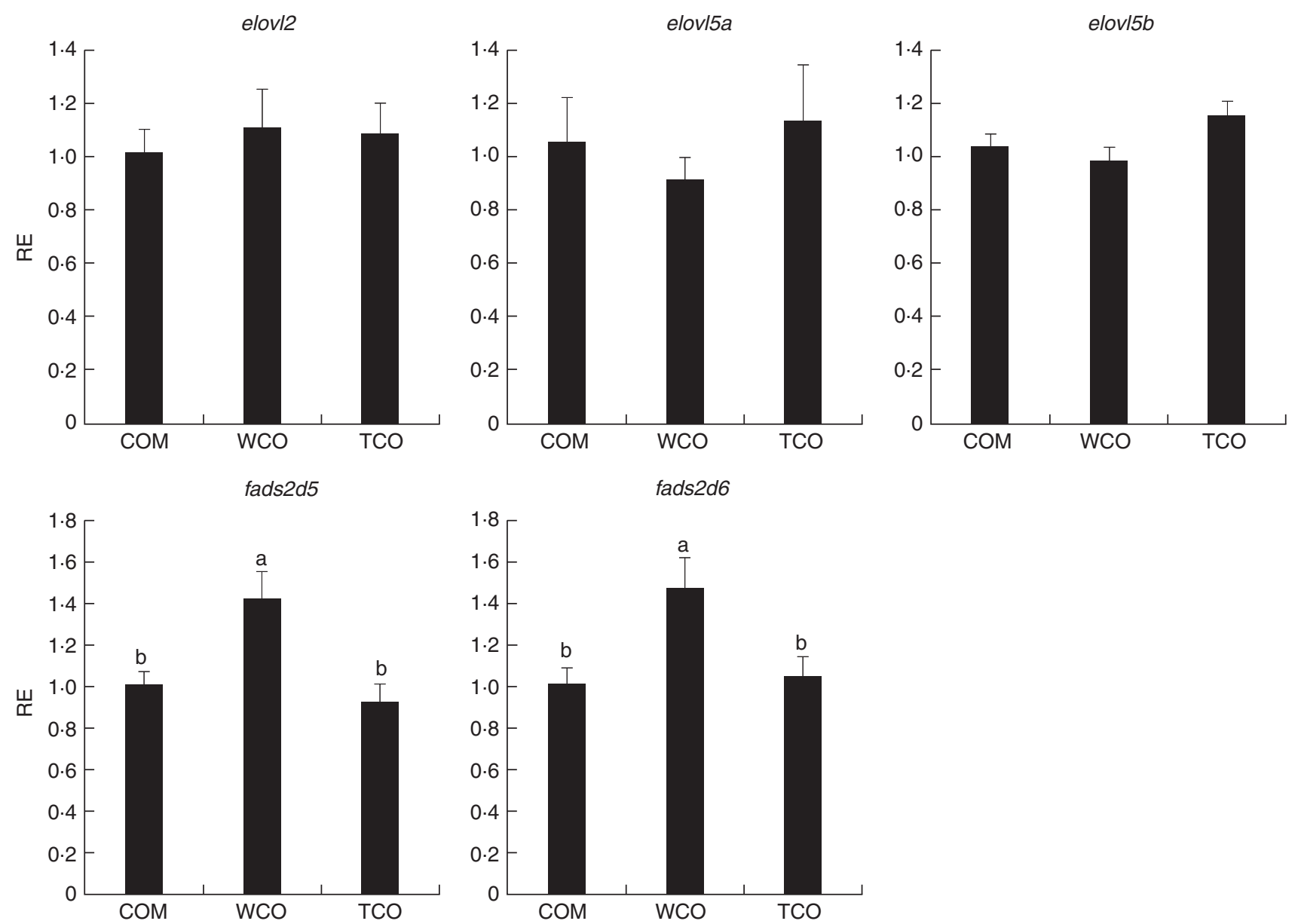

Fig. 4. Relative expression (RE) of genes of the $n-3$ long-chain PUFA (LC-PUFA) biosynthesis pathway in the liver of Atlantic salmon as determined by quantitative PCR. Values are means $(n 6)$, with their standard errors represented by vertical bars (normalised expression ratios). COM, fish/rapeseed oil feed; TCO, transgenic Camelina oil feed; WCO, wild-type Camelina oil feed; elovl2, fatty acyl elongase 2; elovl5a, fatty acyl elongase 5 isoform a; elovl $5 b$, fatty acyl elongase 5 isoform b; fads2d5, delta-5 fatty acyl desaturase; fads2d6, delta- 6 fatty acyl desaturase. ${ }^{a, b}$ Mean values with unlike letters were different among treatments as identified by oneway ANOVA.

\section{Discussion}

The benefits of $n$-3 LC-PUFA on several aspects of human health are widely known and appreciated ${ }^{(2)}$. However, recent studies have highlighted the gradual decrease of these essential fatty acids in the flesh of farmed salmon, reflecting the necessary development of sustainable feeds increasingly formulated with lower levels of marine ingredients that supply the $n-3$ LC-PUFA $^{(4)}$. Previous studies demonstrated the feasibility of oils obtained de novo from transgenic C. sativa to supply $n-3$ LC-PUFA in feeds for Atlantic salmon and sea bream, maintaining growth and enhancing $n$ - 3 LC-PUFA contents in fillet compared with fish reared on feeds formulated with conventional $\mathrm{VO}^{(10-14)}$. The earlier oils from transgenic Camelina supplied either $20 \%$ EPA or $6 \%$ each of EPA and DHA and were compared with feeds formulated with high fishmeal and FO as 'gold standards, ${ }^{,(10-12,14)}$ and also a feed with lower fishmeal and $\mathrm{FO}^{(13)}$. In this study, the latest generation of transgenic oil supplied levels of EPA, DHA and total $n-3$ LC-PUFA as high as many FO, or higher than those from the northern hemisphere, and was specifically tested in order to evaluate its capability to maintain the sustainability of feeds while simultaneously restoring levels of $n$-3 LC-PUFA in farmed salmon to those of a decade ago, before the development of low marine feeds ${ }^{(4)}$.

In the present study, the COM diet was formulated to reflect current commercial feed formulations for salmon and thus included levels of fishmeal and FO that resulted in a dietary $n-3$ LC-PUFA level of around $7 \%$ of total dietary fatty acids. Replacing the added oil with the oil from transgenic Camelina resulted in the $n$ - 3 LC-PUFA content of the TCO diet being almost $24 \%$ of total fatty acids that, in turn, almost doubled the $\mathrm{EPA}+\mathrm{DHA}$ and n-3 LC-PUFA contents of flesh of the TCO-fed fish compared with fish fed the COM diet. Although the fish in the present trial were not market size and thus the data obtained are not directly comparable with the data presented in Sprague et $a l .{ }^{(4)}$, they nonetheless indicate the potential of this thirdgeneration transgenically derived oil to supply sufficient $n-3$ LC-PUFA to restore EPA+DHA levels in farmed salmon to levels last seen a decade ago, thus retaining all the positive health benefits associated with the consumption of fish.

As in previous trials, no differences in terms of growth were observed between fish fed the different feeds, which was not unexpected given that the levels of $n$ - 3 LC-PUFA contained in 

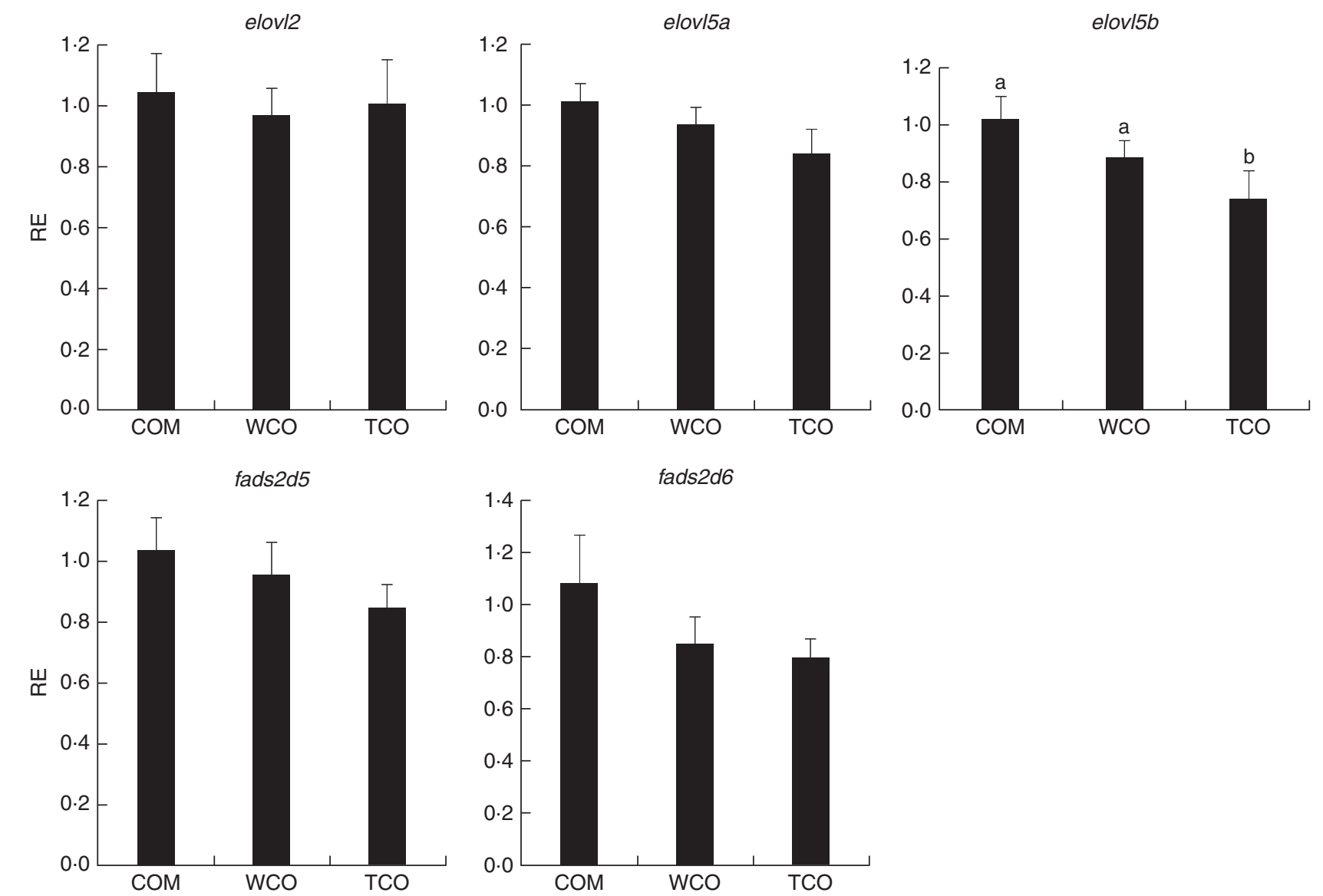

Fig. 5. Relative expression (RE) of genes of the $n-3$ long-chain PUFA (LC-PUFA) biosynthesis pathway in pyloric caeca of Atlantic salmon as determined by quantitative PCR. Values are means $(n 6)$, with their standard errors represented by vertical bars (normalised expression ratios). COM, fish/rapeseed oil feed; TCO, transgenic Camelina oil feed; WCO, wild-type Camelina oil feed; elovl2, fatty acyl elongase 2; elovl5a, fatty acyl elongase 5 isoform a; elovi5b, fatty acyl elongase 5 isoform b; fads2d5, delta-5 fatty acyl desaturase; fads2d6, delta-6 fatty acyl desaturase; ${ }^{\mathrm{a}, \mathrm{b}}$ Mean values with unlike letters were different among treatments identified by one-way ANOVA.

Table 7. Respiratory burst (absorbance per $1 \times 10^{5}$ cells) and phagocytic activity of macrophages isolated from experimental fish after 12 weeks of feeding the experimental diets (Mean values and standard deviations)

\begin{tabular}{|c|c|c|c|c|c|c|c|}
\hline & \multicolumn{2}{|c|}{ cOM } & \multicolumn{2}{|c|}{ WCO } & \multicolumn{2}{|c|}{ TCO } & \multirow[b]{2}{*}{$P$} \\
\hline & Mean & SD & Mean & SD & Mean & SD & \\
\hline Respiratory burst & 0.16 & 0.04 & 0.18 & 0.04 & 0.15 & 0.03 & 0.057 \\
\hline Phagocytic activity & $50 \cdot 0$ & $5 \cdot 9$ & $53 \cdot 3$ & $8 \cdot 1$ & 47.8 & 7.6 & 0.854 \\
\hline
\end{tabular}

COM, fish oil/rapeseed oil feed; WCO, wild-type Camelina oil feed; TCO, transgenic Camelina oil feed.

all the feeds were sufficient to cover the requirements for this species. For instance, total $n$-3 LC-PUFA in fish fed diet WCO was still approximately $5.5 \%$ of total fatty acids representing about $1.1 \%$ of diet, already above the reported EFA requirement level without even considering the high dietary level of $18: 3 n-3^{(34)}$. In agreement with previous trials, Atlantic salmon fed TCO showed a reduced deposition of lipid in whole body and flesh, and, although not always significant, other tissues ${ }^{(12)}$, which could be attributed to the higher contents of EPA and DHA that are known to have anti-adipogenic effects in mammals ${ }^{(35)}$. In addition, the microarray revealed that acsl, a gene involved in lipid biosynthesis, was commonly down-regulated in TCO-fed fish when compared with fish fed COM or WCO, which could indicate inhibition of lipogenesis. Interestingly, the expression of $l p l$ was also down-regulated in TCO-fed fish, which may or may not be consistent with lower lipid levels in tissues. However, at least three different transcripts exist for $l p l$ in Atlantic salmon, and different patterns of nutritional regulation for each isoform have been demonstrated $^{(36)}$. 

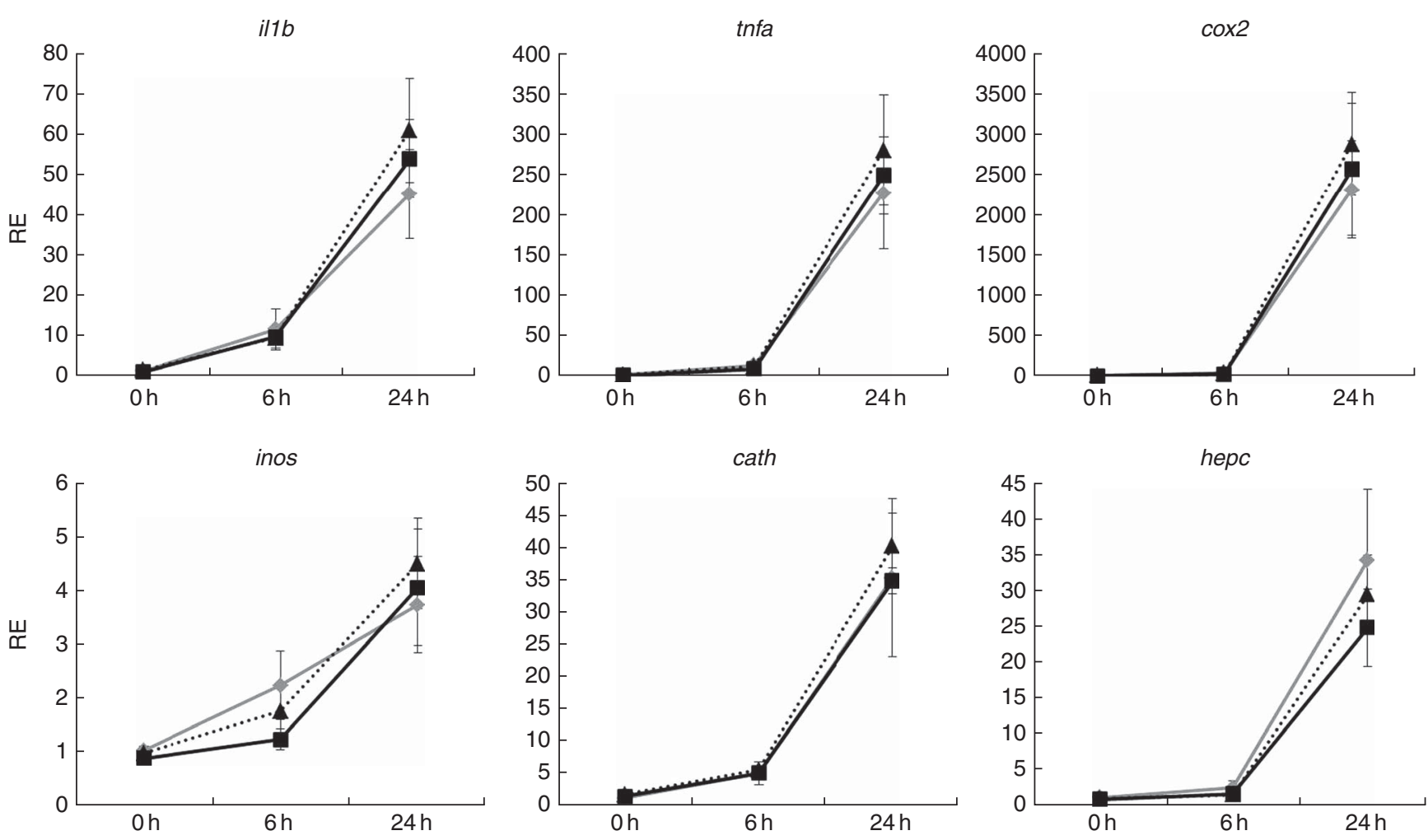

Fig. 6. Relative expression (RE) of genes of inflammation and anti-bacterial activity in head kidney monocytes/macrophages of Atlantic salmon at the end of the experimental trial before $(0 \mathrm{~h})$, or $6 \mathrm{~h}$ and $24 \mathrm{~h}$ after, challenging the cells with lipopolysaccharides. Values are means $(n 6)$, with their standard errors represented by vertical bars (normalised expression ratios). $\_\_$, Fish/rapeseed oil feed; $\_$, wild-type Camelina oil feed; $\cdots \wedge . \cdots$, transgenic Camelina oil feed; cox2, cyclooxygenase 2; inos, inducible nitric oxide synthase; cath, cathelicidin; hepc, hepcidin.

Although there were no effects on growth performance, some differences were observed in lipid and fatty acid digestibility. The ADC for lipid was generally high and affected by dietary lipid source, being slightly higher in the COM and WCO feeds than in TCO feed. Previous studies in several teleost species generally reported highest lipid ADC in feeds containing $\mathrm{FO}^{(37,38)}$. Indeed, in our previous studies, feeds for Atlantic salmon formulated with either wild-type or TCO displayed higher lipid ADC than feeds containing $\mathrm{FO}^{(11,12)}$. However the FO-based feeds were formulated with high levels of fishmeal (49\%) and FO (18\%), and thus the content of $n$-3 LC-PUFA was much higher than in the VO-based feeds, whereas in the present trial diet TCO contained the highest contents of $n-3$ LC-PUFA. These data suggest that lipid ADC is dependent on the fatty acid profile of the feeds and high contents of $n-3$ LC-PUFA enhance lipid digestibility as these fatty acids generally have high $\mathrm{ADC}^{(39,40)}$. Consistent with this, the $\mathrm{ADC}$ for the $n$-3 LC-PUFA were high in this trial and highest in fish fed the TCO diet. Individual fatty acid ADC were also consistent with previous studies where digestibility decreased with increasing chain length, but increased with increasing degree of unsaturation $^{(39,41-42)}$. Although water temperature can also affect the ADC of fatty acids, particularly when dietary FO is substituted by $\mathrm{VO}^{(42)}$, the trial was performed at a constant controlled temperature throughout, and thus differences in digestibility of individual fatty acids between diets cannot be attributed to water temperature. Overall, diet TCO had no major negative effects on fatty acid digestibilities, and differences between diets could be attributed to the different fatty acid profile of the feeds.

Although diet WCO contained the lowest levels of DHA and $n$-3 LC-PUFA, fish fed this feed did not show major differences in the contents of DHA in whole fish or tissues compared with fish fed the COM diet. Anadromous species, such as the salmonids, have the capability to biosynthesise LC-PUFA, with liver and intestine being the most active metabolic sites ${ }^{(43,44)}$. In this respect, fish fed WCO showed up-regulation of hepatic fads $2 d 6$ and fad $62 d 5$, as well as intestinal elovl $5 b$, which could have contributed to the levels of $n$ - 3 LC-PUFA being similar in COM- and WCO-fed fish. Although the COM diet had only a slightly higher level of DHA compared with WCO (3.7 and $2.7 \%$, respectively) and much lower than in TCO (9.0\%), expression levels of desaturases and elongases were similar to those in fish fed TCO. However, the level of $18: 3 n-3$ was almost four times higher in diet WCO than in the COM diet, and it has been suggested that up-regulation of the LC-PUFA biosynthetic pathway in fish fed VO was induced by the level of dietary precursor $(18: 3 n-3)$, as well as low levels of pathway products (e.g. DHA) ${ }^{(45)}$. Therefore, the lower expression of these enzymes in liver and PC of fish fed COM compared with fish fed WCO could be related to the low dietary level of the substrate $18: 3 n-3$.

The PCA analysis partly reflected the physiological functions of each tissue. In general terms, the fatty acid profiles of whole fish and tissues largely reflected that of the diet, consistent with previous studies in Atlantic salmon ${ }^{(31,46,47)}$. The four distinct 
quarters of the plot represent significantly different fatty acid profiles, distinguishing three groups, one per dietary treatment. The fatty acid vectors representing $n-6$ and $n$ - 3 LC-PUFA have significant loadings on the 'TCO' side of the plot, which is directly related to the diet fatty acid profiles. This also explains why $18: 1 n-9$ vector is placed towards 'COM' as this fatty acid is in high concentration in rapeseed oil, which constitutes $75 \%$ of the added oil in that diet. Liver fatty acid profiles from fish fed WCO are located towards the left side of the plot, where fish fed TCO are placed, which reflects the capacity of liver for the synthesis of LC-PUFA. Head kidney of fish fed diet TCO tended to cluster on the left panel reflecting differences in head kidney DHA contents among fish fed the different diets. Although these differences were not significant in the present trial, they were consistent with previous studies in Atlantic salmon, which showed that DHA levels in head kidney reflected the reduced DHA content of VO-based diets ${ }^{(48)}$

The head kidney in fish is an integral tissue of the immune system $^{(49,50)}$, and dietary lipid and PUFA content are known to influence immune function and thus health status of fish ${ }^{(51-53)}$. In this study, no differences were observed in the cellular immune functions evaluated, such as monocyte phagocytic activity or respiratory burst. Previous studies with sustainable feeds have found contradictory results regarding these immune parameters. Although Atlantic salmon fed diets with different VO (100 and $50 \%$ substitution of FO, respectively) did not show altered phagocytic activity nor respiratory burst ${ }^{(54,55)}$ and rainbow trout (Oncorbynchus mykiss) fed increasing concentrations of ARA showed no differences in phagocytosis ${ }^{(56)}$, sea bream fed diets containing VO ( $100 \%$ substitution of FO) showed reduced phagocytic activity ${ }^{(57)}$. Differences in the dietary ARA:EPA ratio can alter the production of immunologically active eicosanoids derived from these fatty acids ${ }^{(58)}$, affecting signal transduction and regulation of gene expression $^{(59)}$. Despite this, the functional assays show no negative effects of the oil from transgenic Camelina on the fish immune system. Furthermore, the expression of several genes related to inflammation and anti-bacterial activity evaluated in monocytes isolated from fish after LPS challenge showed no differences in any of the genes among the dietary treatments at either sampling point. Previously, the expression of the proinflammatory cytokines $i l 1 b$ and tnfa was not changed $12 \mathrm{~h}$ after LPS stimulation in Atlantic salmon after modulation of membrane lipids ${ }^{(55)}$. Therefore, our results were consistent with replacement of dietary FO by $\mathrm{VO}$ in Atlantic salmon feeds having relatively little influence on inflammatory functions of leucocytes. However, in other teleost species, dietary VO can have adverse effects on health/immune system through increasing time to moderate the response up to $7 \mathrm{~d}$ after challenge when $70 \%$ of $\mathrm{FO}$ was substituted by $\mathrm{VO}^{(60)}$. In this respect, the expression of several inflammatory cytokines, as well as the anti-bactericidal gene cath, started to return to basal levels only $72 \mathrm{~h}$ after challenging Atlantic salmon monocytes with $\operatorname{LPS}^{(61)}$.

Transcriptomic analyses showed that diet regulated the expression of a lower number of genes in liver than in PC, with most of the pathways enriched in liver belonging to metabolism, which was consistent given the functions of this tissue.
One of the genes commonly regulated by TCO was acsl, which was down-regulated in fish fed TCO compared with fish fed the other two diets. This gene was also down-regulated in salmon fed a similar EPA + DHA-containing Camelina oil in a previous trial $^{(12)}$. After LC-PUFA enters a cell, acsl converts them to fatty acyl-CoA that can have numerous metabolic fates, including incorporation into TAG or phospholipids, or substrates for $\beta$-oxidation and protein acylation ${ }^{(62)}$. Interestingly, a recent study reported up-regulation of acsl3 in hepatopancreas of grass carp (Ctenopharyngodon idellus) with increasing levels of dietary $\mathrm{ARA}^{(63)}$, which is the opposite trend to that described here, as the TCO feed contained a higher level of ARA compared with the other diets. However, previous studies in Atlantic salmon showed no differences in the expression of acsl in liver between fish fed FO and VO, which had different dietary ARA contents ${ }^{(64)}$. These authors suggested that this gene may function as a general fatty acid activator for several lipid metabolism pathways that are not directly related to $\beta$-oxidation. This was consistent with the present results, given that TCO-fed fish had the lowest lipid content in body and flesh that, in turn, could be related to enhanced $\beta$-oxidation in fish fed this diet. Among the DEG commonly regulated in fish fed TCO, a transcription factor, ppara, was down-regulated in TCO compared with fish fed the other diets. Up-regulation in the expression of this enzyme, concomitant with the expression of fads2, was observed previously in rainbow trout after substitution of dietary $\mathrm{FO}$ with $\mathrm{VO}^{(65)}$.

The intestine is not only the site of nutrient uptake, but also plays an active role in metabolism. Indeed, two genes of carbohydrate metabolism were up-regulated in fish fed TCO compared with fish fed the other diets despite the feeds not differing in carbohydrate content. In an earlier trial with salmon fed a previous version of TCO, intestinal expression of genes of carbohydrate metabolism such as glucose-6-phosphate isomerase and glycerol kinase 5 was up-regulated ${ }^{(13)}$. Previous studies also reported similar effects, probably reflecting that pathways of lipogenesis, lipolysis, glycolysis, gluconeogenesis and pentose phosphate shunt are all interrelated in the regulation of energy homoeostasis ${ }^{(66)}$. No genes were found to be commonly regulated in liver and PC in fish fed TCO, probably reflecting the differing functional roles of each tissue.

This study showed that salmon fed the new oil from transgenic $C$. sativa supplying approximately $24 \% n-3$ LC-PUFA could accumulate almost double the level of EPA and DHA in their body and fillet compared with fish fed a feed reflecting current commercial formulations containing low levels of marine ingredients. This oil also supported good growth without apparently compromising fish health and immune response, as shown by the ex vivo macrophage challenge and tissue transcriptomic responses. Although fish were not of harvest size (final weight, approximately $400 \mathrm{~g}$ ), these data suggest that the new oil from a transgenic oilseed crop has the potential to provide a new generation of salmon feeds that, while maintaining current levels of sustainability, are also able to restore the EPA+DHA levels in harvest-size (approximately $4-5 \mathrm{~kg}$ ) farmed salmon to those last seen a decade ago before the development of low marine feeds. 


\section{Acknowledgements}

The authors thank Dr John B. Taggart for advice and direction with the microarray analyses

This project was funded by a Research Council of Norway Havbruk Programme Award (project no. 245327). The Research Council of Norway had no role in study design, data collection and analysis, decision to publish or preparation of the manuscript.

The authors contributed as follows to the manuscript - study concept and design: J. A. N., O. T., D. R. T. and R. E. O.; formal analysis: M. B. B., K. L., M. S. and L. H.; funding acquisition: J. A. N., D. R. T. and R. E. O.; writing the original draft: M. B. B. and D. R. T.; writing the review and editing: K. L., M. S., O. S., S. U., F. N., O. T., J. A. N. and R. E. O.

The authors declare that there are no conflicts of interest.

\section{Supplementary material}

For supplementary material/s referred to in this article, please visit https://doi.org/10.1017/S0007114518001125

\section{References}

1. Delgado-Lista J, Perez-Martinez $\mathrm{P}$, Lopez-Miranda J, et al. (2012) Long chain omega-3 fatty acids and cardiovascular disease: a systematic review. Br J Nutr 107, S201-S213.

2. Calder PC (2018) Very long-chain $n-3$ fatty acids and human health: fact, fiction and the future. Proc Nutr Soc 77, 52-72.

3. Food and Agriculture Organization (2016) State of World Fisheries and Aquaculture 2016. Rome: FAO of the United Nations.

4. Sprague M, Dick JR \& Tocher DR (2016) Impact of sustainable feeds on omega-3 long-chain fatty acid levels in farmed Atlantic salmon, 2006-2015. Sci Rep 6, 21892.

5. International Society for the Study of Fatty Acids and Lipids (2004) Report of the Sub-Committee on: Recommendations for Intake of Polyunsaturated Fatty Acids in Healthy Adults. Brighton: ISSFAL.

6. European Food Safety Authority (2010) Scientific opinion on dietary reference values for fat, including saturated fatty acids, polyunsaturated fatty acids, monounsaturated fatty acids, trans fatty acids, and cholesterol. EFSA panel on dietetic products, nutrition and allergies (NDA). EFSA J 8, 1461.

7. Salunkhe DK, Adsule RN, Chavan JK, et al. (1992) World Oilseeds: Chemistry, Technology and Utilization. New York: VanNostrand Reinhold Company.

8. Ruiz-Lopez N, Haslam RP, Napier JA, et al. (2014) Successful high-level accumulation of fish oil omega-3 long-chain polyunsaturated fatty acids in a transgenic oilseed crop. Plant J 77, 198-208.

9. Usher S, Han L, Haslam RP, et al. (2017) Tailoring seed oil composition in the real world: optimising omega-3 long chain polyunsaturated fatty acid accumulation in transgenic Camelina sativa. Sci Rep 7, 6570.

10. Betancor MB, Sprague M, Usher S, et al. (2015) A nutritionallyenhanced oil from transgenic Camelina sativa effectively replaces fish oil as a source of eicosapentaenoic acid for fish. Sci Rep 5, 8104.

11. Betancor MB, Sprague M, Sayanova O, et al. (2015) Evaluation of a high-EPA oil from transgenic Camelina sativa in feeds for Atlantic salmon (Salmo salar L.): effects on tissue fatty acid composition, histology and gene expression. Aquaculture 444, 1-12.

12. Betancor MB, Sprague M, Sayanova O, et al. (2016) Nutritional evaluation of an EPA-DHA oil from transgenic Camelina sativa in feeds for post-smolt Atlantic salmon (Salmo salar L.). PLOS ONE 11, e0159934.

13. Betancor MB, Li K, Sprague M, et al. (2017) An oil containing EPA and DHA from transgenic Camelina sativa to replace marine fish oil in feeds for Atlantic salmon (Salmo salar L.): effects on intestinal transcriptome, histology, tissue fatty acid profiles and plasma biochemistry. PLOS ONE 12, e0175415.

14. Betancor MB, Sprague M, Montero D, et al. (2016) Replacement of marine fish oil with de novo omega-3 oils from transgenic Camelina sativa in feeds for gilthead sea bream (Sparus aurata). Lipids 51, 1171-1191.

15. Montero D \& Izquierdo M (2011) Welfare and health of fish fed vegetable oils as alternative lipid sources to fish oil. In Fish Oil Replacement and Alternative Lipid Sources in Aquaculture Feeds, pp. 439-485 [GM Turchini, WK Ng and DR Tocher, editors]. Boca Raton, FL: CRC Press.

16. Tort L (2011) Stress and immune modulation in fish. Dev Comp Immunol 35, 1366-1375.

17. Austreng E (1978) Digestibility determination in fish using chromic oxide marking and analysis of contents from different segments of the gastrointestinal tract. Aquaculture 13, $265-272$

18. Association of Official Analytical Chemists (2000) Official Methods of Analysis. Washington, DC: AOAC.

19. Folch J, Lees N \& Sloane-Stanley GH (1957) A simple method for the isolation and purification of total lipides from animal tissues. J Biol Chem 226, 497-509.

20. Christie WW (2003) Lipid Analysis, 3rd ed. Bridgwater: Oily Press.

21. Tocher DR \& Harvie DG (1988) Fatty acid compositions of the major phosphoglycerides from fish neural tissues; (n-3) and (n-6) polyunsaturated fatty acids in rainbow trout (Salmo gairdneri) and cod (Gadus morhua) brains and retinas. Fish Physiol Biochem 5, 229-239.

22. Choi HS, Kim JW, Cha YN, et al. (2006) A quantitative nitroblue tetrazolium assay for determining intracellular superoxide anion production in phagocytic cells. I Immunoassay Immunochem 27, 31-44.

23. Secombes CJ (1990) Isolation of salmonid macrophages and analysis of their killing activity. In Techniques in Fish Immunology, pp. 137-154 [JS Stolen, TC Fletcher, DP Anderson, et al., editors]. New Haven, NJ: SOS Publication.

24. Pulsford AL, Crampe M, Lagnston A, et al. (1995) Modulatory effects of disease, stress, copper, TBT and vitamin E on the immune system of flatfish. Fish Shellfish Immunol 5, 631-643.

25. Russo R, Shoemaker CA, Panangala VS, et al. (2009) In vitro and in vivo interaction of macrophages from vaccinated and non-vaccinates channel catfish (Ictalurus punctatus) to Edwarsiella ictaluri. Fish Shellfish Immunol 26, 543-552.

26. Jensch-Junior BE, Presinotti LN, Borges JCS, et al. (2006) Characterization of macrophage phagocytosis of the tropical fish Prochilodus scrofa (Steindachner, 1881). Aquaculture 251, 509-515.

27. Morais S, Edvardsen RB, Tocher DR, et al. (2012) Transcriptomic analyses if intestinal gene expression of juvenile Atlantic cod (Gadus morbua) fed diets with Camelina oil as replacement for fish oil. Comp Biochem Physiol 161B, 283-293.

28. Tacchi L, Secombes CJ, Bickerdike R, et al. (2012) Transcriptomic and physiological responses to fishmeal substitution with plant proteins in formulated feed in farmed Atlantic salmon (Salmo salar). BMC Genomics 13, 363. 
29. Martinez-Rubio L, Evensen $\varnothing$, Krasnov A, et al. (2014) Effects of functional feeds on the lipid composition, transcriptomic responses and pathology in heart of Atlantic salmon (Salmo salar L.) before and after experimental challenge with Piscine Myocarditis Virus (PMCV). BMG Genomics 15, 462.

30. Bicskei B, Bron JE, Glover KA, et al. (2014) A comparison of gene transcription profiles of domesticated and wild Atlantic salmon (Salmo salar L.) at early life stages, reared under controlled conditions. BMC Genomics 15, 884.

31. Betancor MB, Howarth FJE, Glencross BD, et al. (2014) Influence of dietary docosahexaenoic acid in combination with other long-chain polyunsaturated fatty acids on expression of biosynthesis genes and phospholipid fatty acid compositions in tissues of post-smolt Atlantic salmon (Salmo salar). Comp Biochem Physiol B 172-173, 74-89.

32. Rozen S \& Skaletsky H (2000) Primer3 on the WWW for general users and for biologist programmers. Methods Mol Biol 132, 365-386.

33. Kuleshov MV, Jones MR, Rouillard AD, et al. (2016) Enrichr: a comprehensive gene set enrichment analysis web server 2016 update. Nucleic Acids Res 8, W90-W97.

34. National Research Council (2011) Nutrient Requirements of Fish and Shrimp. Washington, DC: The National Academies Press.

35. Dentin R, Benhamed F, Pégorier JP, et al. (2005) Polyunsaturated fatty acids suppress glycolytic and lipogenic genes through the inhibition of ChREBP nuclear protein translocation. J Clin Invest 115, 2843-2854.

36. Morais S, Pratoomyot J, Torstensen BE, et al. (2011) Diet $\mathrm{x}$ genotype interactions in hepatic cholesterol and lipoprotein metabolism in Atlantic salmon (Salmo salar) in response to replacement of dietary fish oil with vegetable oil. Br J Nutr 106, 1457-1469.

37. Menoyo D, Lopez-Bote CJ, Diez A, et al. (2007) Impact of $n-3$ fatty acid chain length and $n-3 / n-6$ ratio in Atlantic salmon (Salmo salar) diets. Aquaculture 267, 248-259.

38. Martins D, Valente LMP \& Lall SP (2009) Apparent digestibility of lipid and fatty acids in fish oil poultry fat and vegetable oil diets by Atlantic halibut, Hippoglossus hippoglossus L. Aquaculture 294, 132-137.

39. Sigurgisladottir S, Lall SP, Parrish CC, et al. (1992) Cholestane as a digestibility marker in the absorption of polyunsaturated fatty acid ethyl esters in Atlantic salmon. Lipids 27, 418-424.

40. Caballero MJ, Obach A, Rosenlund G, et al. (2002) Impact of different dietary lipid sources on growth, lipid digestibility, tissue fatty acid composition and histology of rainbow trout, Oncorbynchus mykiss. Aquaculture 214, 253-271.

41. Johnsen RI, Grahl-Nielsen O \& Roem A (2000) Relative absorption of fatty acids by Atlantic salmon Salmo salar from different diets, as evaluated by multivariate statistics. Aquacult Nutr 6, 255-261.

42. Ng WK, Sigholt T \& Bell JG (2004) The influence of environmental temperature on the apparent nutrient and fatty acid digestibility in Atlantic salmon (Salmo salar L.) fed finishing diets containing different blends of fish oil, rapeseed oil and palm oil. Aquacult Res 35, 1228-1237.

43. Morais S, Monroig O, Zhen X, et al. (2009) Highly unsaturated fatty acid synthesis in Atlantic salmon: characterization of ELOVL5- and ELOVL2-like elongases. Marine Biotechnol 11, 627-639.

44. Monroig O, Zheng X, Morais S, et al. (2010) Mutiple genes for functional $\Delta 6$ fatty acyl desaturases (Fad) in Atlantic salmon (Salmo salar L.): gene and cDNA characterization, functional expression, tissue distribution and nutritional regulation. Biochim Biophys Acta Mol Cell Biol Lipids 1801, 1072-1081.
45. Vagner M \& Santigosa E (2011) Characterization and modulation of gene expression and enzymatic activity of delta6-desaturase in teleost: a review. Aquaculture 315, 131-143.

46. Bell JG, Tocher DR, Henderson RJ, et al. (2003) Altered fatty acid compositions in Atlantic salmon (Salmo salar) fed diets containing linseed and rapeseed oils can be partially restored by a subsequent fish oil finishing diet. J Nutr 33, 2793-2801.

47. Bransden MP, Carter CG \& Nichols PD (2003) Replacement of fish oil with sunflower oil in feeds for Atlantic salmon (Salmo salar L.): effect on growth performance, tissue fatty acid composition and disease resistance. Comp Biochem Physiol B 135, 611-625.

48. Gjøen T, Obach A, Røsjø C, et al. (2004) Effect of dietary lipids on macrophage function, stress susceptibility and disease resistance in Atlantic salmon (Salmo salar). Fish Physiol Biochem 30, 149-161.

49. Tort L, Balasch JC \& Mackenzie S (2003) Fish immune system. A crossroads between innate and adaptive responses. Immunologia 22, 277-286.

50. Gjøen T, Kleveland EJ, Moya-Falcón C, et al. (2007) Effects of dietary thia fatty acids on lipid composition, morphology and macrophage function of Atlantic salmon (Salmo salar L.) kidney. Comp Biochem Physiol 148B, 103-111.

51. Waagbø R (1994) The impact of nutritional factors on the immune system in Atlantic salmon, Salmo salar L: a review. Aquacult Res 25, 175-197.

52. Lall SP (2000) Nutrition and health of fish. In Avances en Nutricion Acuicola $V$. Proceedings of the $V$ International Symposium on Fish Nutrition, 19-22 November 2000 pp. 13-23 [LE Cruz-Suarez, D Ricque-Marie, M Tapia-Salazar, et al., editors]. Merida, Yucatan.

53. Martínez-Rubio L, Wadsworth S, Vecino JLG, et al. (2013) Effect of dietary digestible energy content on expression of genes of lipid metabolism and LC-PUFA biosynthesis in liver of Atlantic salmon (Salmo salar L). Aquaculture 384-387, 94-103.

54. Bell JG, Ashton I, Secombes CJ, et al. (1996) Dietary lipid affects phospholipid fatty acid compositions, eicosanoid production and immune function in Atlantic salmon (Salmo salar). Prostaglandins Leukot Essent Fatty Acids 54, 73-182.

55. Seierstad S, Haugland $\varnothing$, Waagbø R, et al. (2009) Proinflammatory cytokine expression and respiratory burst activity following replacement of fish oil with rapeseed oil in the feed for Atlantic salmon (Salmo salar L.). Aquaculture 289, 212-218.

56. Dantagnan P, Gonzalez K, Hevia M, et al. (2017) Effect of the arachidonic acid/vitamin $\mathrm{E}$ interaction on the immune response of juvenile Atlantic salmon (Salmo salar) challenged against Piscirickettsia salmonis. Aquac Nutr 23, 710-720.

57. Montero D, Grasso V, Izquierdo MS, et al. (2008) Total substitution of fish oil by vegetable oils in gilthead sea bream (Sparus aurata) diets: effects on hepatic $\mathrm{Mx}$ expression and some immune parameters. Fish Shellfish Immunol 24, $147-155$

58. Ganga R, Bell JG, Montero D, et al. (2005) Effect of feeding gilthead seabream (Sparus aurata) with vegetable lipid sources on two potential immunomodulatory products: prostanoids and leptins. Comp Biochem Physiol 142, 410-418.

59. Yaqoob P (2004) Fatty acids and the immune system: from basic science to clinical applications. Proc Nutr Soc 63, 89-104.

60. Montero D, Mathlouthi F, Tort L, et al. (2010) Replacement of dietary fish oil by vegetable oil affects humoral immunity and expression of pro-inflammatory cytokines genes in gilthead sea bream Sparus aurata. Fish Shellfish Immunol 29, 1073-1081. 
61. Seppola M, Mikkelsen H, Johansen A, et al. (2015) Ultrapure LPS induces inflammatory and antibacterial responses in vitro by exogenous sera in Atlantic cod and Atlantic salmon. Fish Shellfish Immunol 44, 66-78.

62. Mashek DG, Li LO \& Coleman RA (2006) Rat long-chain acylcoA synthetase mRNA, protein, and activity vary in tissue distribution and in response to diet. J Lipid Res 47, 2004-2010.

63. Tian JJ, Lei CX, Ji H, et al. (2017) Role of cyclooxygenasemediated metabolites in lipid metabolism and expression of some immune-related genes in juvenile grass carp (Ctenopharyngodon idellus) fed arachidonic acid. Fish Physiol Biochem 43, 703-717.
64. Torstensen BE, Nanton DA, Olsvik PA, et al. (2009) Gene expression of fatty acid-binding proteins, fatty acid transport proteins (cd36 and FATP) and $\beta$-oxidation-related genes in Atlantic salmon (Salmo salar L.) fed fish oil or vegetable oil. Aquacult Nutr 15, 440-451.

65. Dong X, Tan P, Cai Z, et al. (2017) Regulation of FADS2 transcription by SREBP-1 and PPAR- $\alpha$ influences LC-PUFA biosynthesis in fish. Sci Rep 7, 40024.

66. Morais S, Pratoomyot J, Taggart JB, et al. (2011) Genotypespecific responses in Atlantic salmon (Salmo salar) subject to dietary fish oil replacement by vegetable oil: a liver transcriptomic analysis. BMC Genomics 12, 255. 